\title{
Heatwave frequency and seedling death alter stress-specific emissions of volatile organic compounds in Aleppo pine
}

\author{
Benjamin Birami ${ }^{1,4}\left(\mathbb{D} \cdot\right.$ Ines Bamberger ${ }^{2} \cdot$ Andrea Ghirardo $^{3} \cdot$ Rüdiger Grote $^{1} \cdot$ Almut Arneth $^{1}$. \\ Elizabeth Gaona-Colmán ${ }^{1} \cdot$ Daniel Nadal-Sala ${ }^{1} \cdot$ Nadine K. Ruehr $^{1}$
}

Received: 10 July 2020 / Accepted: 23 March 2021 / Published online: 9 April 2021

(c) The Author(s) 2021

\begin{abstract}
Biogenic volatile organic compounds (BVOC) play important roles in plant stress responses and can serve as stress indicators. While the impacts of gradual environmental changes on BVOCs have been studied extensively, insights in emission responses to repeated stress and recovery are widely absent. Therefore, we studied the dynamics of shoot gas exchange and BVOC emissions in Pinus halepensis seedlings during an induced moderate drought, two four-day-long heatwaves, and the combination of drought and heatwaves. We found clear stress-specific responses of BVOC emissions. Reductions in acetone emissions with declining soil water content and transpiration stood out as a clear drought indicator. All other measured BVOC emissions responded exponentially to rising temperatures during heat stress (maximum of $43^{\circ} \mathrm{C}$ ), but monoterpenes and methyl salicylate showed a reduced temperature sensitivity during the second heatwave. We found that these decreases in monoterpene emissions between heatwaves were not reflected by similar declines in their internal storage pools. Because stress intensity was extremely severe, most of the seedlings in the heat-drought treatment died at the end of the second heatwave (dark respiration ceased). Interestingly, BVOC emissions (methanol, monoterpenes, methyl salicylate, and acetaldehyde) differed between dying and surviving seedlings, already well before indications of a reduced vitality became visible in gas exchange dynamics. In summary, we could clearly show that the dynamics of BVOC emissions are sensitive to stress type, stress frequency, and stress severity. Moreover, we found indications that stress-induced seedling mortality was preceded by altered methanol, monoterpene, and acetaldehyde emission dynamics.
\end{abstract}

Keywords BVOC emissions $\cdot$ Drought $\cdot$ Heatwaves $\cdot$ Mortality $\cdot$ Stress-specific

Communicated by Amy Marie Trowbridge.

Benjamin Birami

benjamin.birami@kit.edu; benjamin.birami@uni-bayreuth.de

1 Karlsruhe Institute of Technology KIT, Institute of Meteorology and Climate Research-Atmospheric Environmental Research, 82467 Garmisch-Partenkirchen, Germany

2 University of Bayreuth, Bayreuth Center of Ecology and Environmental Research (BayCEER), Atmospheric Chemistry, Dr.-Hans-Frisch-Straße 1-3, 95448 Bayreuth, Germany

3 Research Unit Environmental Simulation, Institute of Biochemical Plant Pathology, Helmholtz Zentrum München, Ingolstädter Landstr. 1, 85764 Neuherberg, Germany

4 University of Bayreuth, Chair of Plant Ecology, Universitätsstraße 30, 95440 Bayreuth, Germany

\section{Introduction}

Climate change is expected to cause not only higher temperatures and a higher variability of precipitation, but also to produce more frequent and more intense extreme events such as heatwaves and drought spells (Baldwin et al. 2019; Kornhuber et al. 2019). This is likely to intensify forest degradation as has been already observed in many areas worldwide (Anderegg et al. 2019; Brodribb et al. 2020; Hartmann et al. 2018a). In particular, the co-occurrences of high temperatures and low water availability seems to damage tree growth and trigger mortality (Choat et al. 2018; Hartmann et al. 2018b; Ruehr et al. 2019; Williams et al. 2013). Nevertheless, the specific mechanisms of this phenomenon are still heavily discussed, since it is unclear how drought and heat effects interact and when stress-induced mortality actually occurs (Hammond et al. 2019; Hartmann et al. 2018b). 
At the onset of severe droughts, trees initially react by closing their stomata to prevent excessive water loss, which in turn leads to suboptimal leaf internal carbon dioxide concentrations $\left(C_{\mathrm{i}}\right)$ and eventually limits photosynthesis $\left(A_{\text {net }}\right)$ (Brunner et al. 2015; Gupta et al. 2020). As drought intensifies, the water potential of the conductive xylem can drop below a species-specific critical threshold (Anderegg et al. 2019; Ruehr et al. 2019), followed by embolism impairing water transport. At this point, the probability of droughtinduced mortality increases (Hammond et al. 2019) because living tissue becomes dehydrated (Körner 2019). If the stress is not lethal, the organism requires carbon for repair and/or recovery processes, which is why individuals might still die sometime after the stress ceased, if sufficient reserves are not available (Ruehr et al. 2019).

High temperatures have the potential to increase physiological drought stress by increasing the vapor pressure deficit (VPD) of the surrounding air, which then leads to an increase in water loss by transpiration $(E)$ (Panek and Goldstein 2001). Heat stress is amplified by limited water availability because reduced evaporation limits the possibility for cooling the leaf surface (Ruehr et al. 2016; Williams et al. 2013). High temperatures will first speed up biochemical reactions, reducing the lifetime of proteins and causing imbalances primarily in the energy-providing pathways (light assimilation, photosynthesis, respiration) (Niinemets 2018). Apart from higher resource requirements, this response enhances the formation of harmful reactive oxidative species (ROS) (Escandón et al. 2016; Song et al. 2014). Finally, a very high temperature may well lead to direct membrane damages, induce necrosis and eventually tissue senescence (Colombo and Timmer 1992; Daniell et al. 1969; Hüve et al. 2011) and can also lead to mortality (Birami et al. 2018).

Apart from opening stomata to increase evaporative cooling, which increases the risk of dehydration, the production of biogenic volatile organic compounds (BVOC) is another response to cope with abiotic stress (Spinelli et al. 2011). In particular terpenoids such as isoprene, monoterpenes (MT), and sesquiterpenes (SQT) play important roles in detoxifying reactive substances, regardless if these are taken up or formed internally in response to heat or radiation (Nogués et al. 2015; Vickers et al. 2009). A second protective mechanism is the stabilization of membranes that is established by the incorporation of isoprene or MT (Loreto et al. 1998; Mahajan et al. 2019). In addition, it seems that isoprenoids could also act as signaling molecules inducing a network of transcription factors that may play a role for stress tolerance (Harvey and Sharkey 2016).

Under stress conditions, new BVOCs may be emitted, or constitutively emitted BVOCs may increase several-folds above their unstressed rates (Guidolotti et al. 2019; Joó et al. 2011; Yáñez-Serrano et al. 2019). Such stress-induced
BVOC emissions can either originate from de novo biosynthesis or are previously formed compounds, which had been stored in specific structures (e.g. MT from resin ducts in coniferous species) (Ghirardo et al. 2010; Turan et al. 2019). Typically damage-released compounds besides isoprene, mono- and sesquiterpenes, are green leaf volatiles, methanol and acetaldehyde as well as methyl salicylate (MeSa) (Guidolotti et al. 2019; Joó et al. 2011).

Thus, with the ongoing rise of temperatures as well as increased frequency and intensity of heatwaves and drought spells, changes in BVOC emissions can be expected. While most volatile emissions have been found to generally increase with temperature (Niinemets et al. 2010), this effect is less clear in response to drought and emissions patterns differ with species and drought intensity. Some authors found that emissions are increased at mild drought stress, while a chronic, prolonged drought decreases emissions (Dani et al. 2015; Eller et al. 2016; Llusia et al. 2016). However, significant amounts of MT emissions were still found in Aleppo pines at very dry conditions where photosynthesis was already dramatically reduced (Seco et al. 2017). So, not only the intensity but also the composition of emissions is likely to change, particularly under extreme events, which would influence vegetation-climate interactions (Harper and Unger 2018; Sporre et al. 2019). BVOCs take part in air chemistry processes and affect regional ozone concentration as well as aerosol abundance, with secondary impacts on cloud formation and radiation balance (Porter and Heald 2019; Zhao et al. 2017). Globally, BVOCs reduce the abundance of radicals in the air and thus increase the longevity of greenhouse gases, i.e. methane (Fuentes et al. 2001; Monson and Holland 2001). Hence, elucidating the variety of BVOC emission responses to different intensity, elongation, and frequency of stress conditions is needed.

Monoterpenes can be found in most conifers, becoming a main compound of resin, stored in large amounts in specialized resin ducts (Celedon and Bohlmann 2019; Turner et al. 2019). Despite representing large storage pools (up to $0.8 \%$ of the dry needle matter, (Vanhatalo et al. 2018)), it has been found that in Scots pine 10-58\% of the emitted MT can still be synthesized de novo from freshly fixed atmospheric carbon (Ghirardo et al. 2010; Kleist et al. 2012). Similarly, about half of MT measured in Aleppo pine in spring were estimated to be light-dependent (Llusia et al. 2016). Apart from specialized storages, MT can be stored non-specifically as glycosylates in micro vesicles, or be integrated with biological membranes (Nagegowda 2010; Yazaki et al. 2017), and even accumulate in epicuticular wax layers (Joensuu et al. 2016). From these unspecific storages, MT can be directly released. Apart from MT, typically stress-induced terpenoids are sesquiterpenes (SQT), which play a role in plant-to-plant signaling in tree defense strategies against insects and pathogens (Joó et al. 2011; Kleist et al. 2012). 
In addition to terpenoid emissions, a relatively large amount of BVOCs are oxygenated compounds that originate from various biochemical pathways (Grote et al. 2019). The most abundant in the atmosphere is methanol (Jacob 2005), which is formed mainly during cell wall development and can act as a stress signal transmitter (Dorokhov et al. 2018). Other short-chain volatile organic compounds (VOC) are derived downstream of glycolysis from either pyruvate or acetyl-CoA (Fall 2003; Grote et al. 2019), during anoxic stress conditions (Kelsey et al. 2011; Kreuzwieser et al. 1999), indicating substrate overflow mechanisms (Karl et al. 2002). Thus, acetaldehyde, ethanol, and acetone are often produced in roots, phloem or cambial tissues (Kimmerer and Stringer 1988; Rissanen et al. 2020) where they remain dissolved until they reach the leaves via the transpiration stream within the plant (Rissanen et al. 2018). Some of them, especially methanol and acetaldehyde are indicators of high metabolic activity, often found when tissue damage occurs (Fall et al. 1999; Kreuzwieser et al. 1999; Loreto et al. 2006; Portillo-Estrada et al. 2015; Turan et al. 2019).

Dependencies of constitutively emitted BVOCs on temperature have been described extensively (Grote et al. 2014; Guenther et al. 1993; Niinemets et al. 2002), while deficits still exist in representing stress-induced BVOC emissions. Particularly, the emission responses to repeated heat stress under well-watered or droughtexposed conditions have not received much attention so far. BVOC emission might be affected by potential acclimation responses and the production of compounds might be limited by decreasing carbon supply (Jud et al. 2016; Vanzo et al. 2015). In the case of storage-released terpenoids, the storage capacity might decline and limit emissions during repeated and/or long-term heat stress (Schurgers et al. 2009). Finally, it remains unknown if BVOC emissions of coniferous trees prone to death differ from surviving trees, and hence may provide a deathpreceding indicator of mortality.

To investigate BVOC responses to heat and combined heat-drought stress, we selected Aleppo pine, a tree species common to the dry and semi-arid regions in the Mediterranean area (Mauri et al. 2016). The seedlings used here originate from the Yatir forest in Israel, an Aleppo pine plantation at the border to the Negev desert. Based on the literature, we hypothesize that (1) Aleppo pine will change BVOC emissions quantitatively and qualitatively under a combined heat and drought stress and that this response differs from that to only one of these stresses. (2) Emission bouquets differ between first and repeated stress caused by a reduction of storage compounds. (3) If stress induces seedling mortality, the emission is different from those of surviving seedlings.

\section{Materials and methods}

\section{Plant cultivation}

Aleppo pine (Pinus halepensis, Miller) seedlings were cultivated from seeds in a controlled greenhouse environment in Garmisch-Partenkirchen, Germany (732 m a.s.1., $47^{\circ} 28^{\prime} 32.87^{\prime \prime} N, 11^{\circ} 3^{\prime} 44.03^{\prime \prime} E$ ). Seed material originated from five different trees in a 55-year-old Aleppo pine plantation in Israel (Yatir forest, IL-Yat, $650 \mathrm{~m}$ a.s.l., $\left.31^{\circ} 20^{\prime} 49.2^{\prime \prime} \mathrm{N}, 35^{\circ} 03^{\prime} 07.2^{\prime \prime} \mathrm{E}\right)$. The genetic heritage is not clear (Schiller and Atzmon 2009), but due to high levels of heterozygosity, seedling offspring may be referred to as a mixed F1 population (Atzmon et al. 2004; Korol and Schiller 1996). Seedlings (4 weeks old, July 2015) were transplanted to $1 \mathrm{~L}$ pots containing mineral substrate $(2: 8)$ of quartz sand ( $0.7 \mathrm{~mm}$ and $1-2 \mathrm{~mm}$ ) and vermiculite (ca. $3 \mathrm{~mm}$ ) with $2 \mathrm{~g}$ of slow-release fertilizer (Osmocote ${ }^{\circledR}$ Exact + TE 3-4 months fertilizer 16-9-12+2MgO + TE, Everis International B.V., Heerlen, The Netherlands). Seven-month-old seedlings (January 2016) were planted in larger pots $(2.5 \mathrm{~L})$ containing mineral substrate (1:2:1) of quartz sand (1-2 mm): quartz sand $(4-6 \mathrm{~mm})$ : vermiculite $(3 \mathrm{~mm})$ and $6 \mathrm{~g}$ of slowrelease fertilizer (Osmocote ${ }^{\circledR}$ Exact + TE 5-6 month fertilizer $15-9-12+2 \mathrm{MgO}+\mathrm{TE})$. Air temperature and relative humidity $(\mathrm{RH})$ during cultivation (Table $\mathrm{S} 1$ ) were set to mimic the monthly mean of temperature and humidity data of the Yatir forest (averaged over ten years) as described previously (Birami et al. 2018). The position of the seedlings within the greenhouse compartment was iterated randomly to avoid any positioning effect (Fig. 1). Nine-month-old seedlings were divided into four treatments in March 2016: control, heat, drought, and heat-drought one month before initiating the heatwave experiment (experiment in April 2016, Fig. 1). Therefore, 30 seedlings each of the control and drought treatments, as well as the heat and heat-drought treatments were placed into two adjacent environmentallycontrolled compartments using a randomized block design (Birami et al. 2018; Ruehr et al. 2016). Substrate-specific calibrated moisture sensors (10HS, Decagon Devices, Inc., WA, USA) have been installed ( $n=10$ per treatment). Per treatment, four seedlings each were equipped with a gas exchange cuvette ( $n=4$ per treatment; see method Sect. 2.3 for details). Therefore, iteration of the seedlings' placement during the experimental phase was no longer possible.

\section{Experimental setup}

Seedlings of the heat and heat-drought treatment were exposed to two heatwaves with stepwise increasing temperatures and vapor pressure deficit (VPD) (Fig. S1). The 


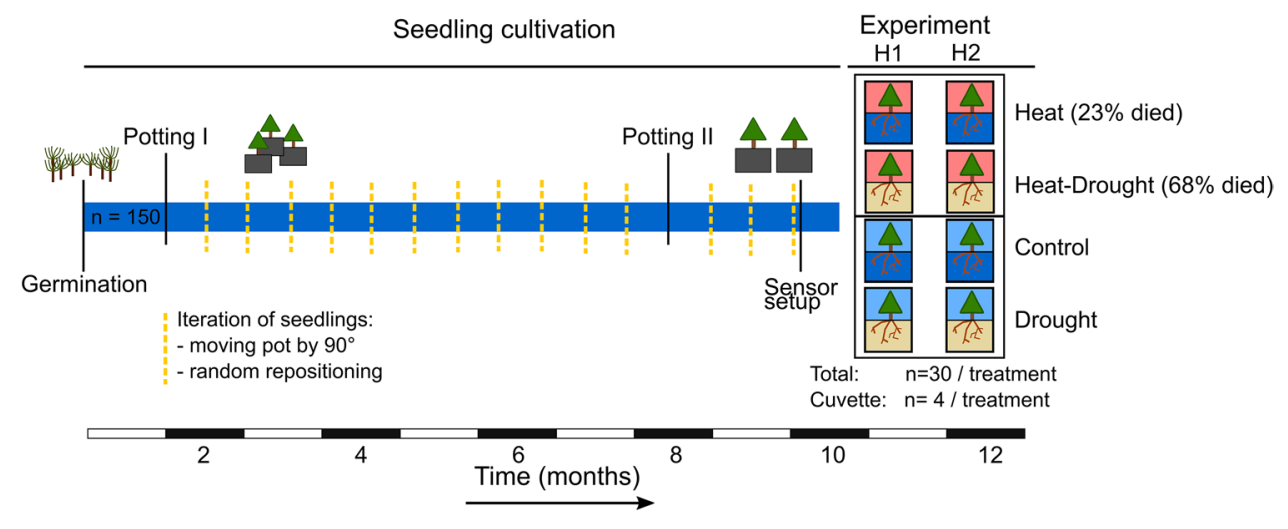

Fig. 1 Experimental timeline: from Aleppo pine seedling germination until the drought was initiated and two heat experiments (each $4 \mathrm{~d})$ were conducted 10 months later. During the cultivation phase, all seedlings were grown in one of the climate-controlled greenhouse compartments and positioning among seedlings was regularly iterated. Before the stress experiment was initiated the seedlings were randomly placed in two separate greenhouse compartments to conduct heatwave scenarios. In each treatment, four seedlings were placed in light-transmitting gas exchange cuvettes coated with Teflon on the inside. In the heat and heat-drought treatment seedlings died due to overheating during the course of the experiment, mostly during the short recovery phase between heatwave 1 (H1) and heatwave 2 (H2) (see Birami et al. 2018 for details). Note that also seedlings placed in the gas exchange cuvettes died: one seedling in the heat treatment and three seedlings in the heat-drought treatment

the end of the 10 min measurement cycle; 3-times per day). The average light intensity was $416 \pm 105 \mu \mathrm{mol} \mathrm{m} \mathrm{m}^{-2} \mathrm{~s}^{-1}$ during day-time and water vapor in the greenhouse compartments and gas exchange cuvettes was kept constant, which resulted in $20-40 \% \mathrm{RH}$ and an increase of VPD to a maximum of $7.5 \mathrm{kPa}$ during the heatwaves in the greenhouse compartment, similar to VPD conditions at the Yatir forest during heatwave periods in early summer (Tatarinov et al. 2016). The 1-month drought period was initiated (DOY 114) 4 days before the first heatwave (DOY 118-121) and ended (DOY 138) 7 days after the second heatwave (DOY 128-131). Irrigation was reduced to a relative substrate water content (rSWC) of about $15 \%$ in the drought and heat-drought treatment, while it was kept between 40 and 50\% under well-watered and control conditions (Fig. S1).
Table 1 Air temperature $\left(\mathrm{T}_{\text {Air }}\right)$ and vapor pressure deficit (VPD) before, during the two heatwaves and after. Averages $( \pm 1 \mathrm{SD})$ and minima and maxima are given for each day of the heatwaves and for the periods before, between and after the heatwaves. Note minima occurred during nighttime ( $8 \mathrm{~h})$, maxima during day-time (16 h)

\begin{tabular}{|c|c|c|c|c|c|c|c|}
\hline & & \multicolumn{3}{|c|}{$T_{\text {Air }}\left[{ }^{\circ} \mathrm{C}\right]$} & \multicolumn{3}{|c|}{ VPD [kPa] } \\
\hline & & Min & Mean & Max & Min & Mean & Max \\
\hline & Before & 11.1 & $18.3 \pm 2.7$ & 24.8 & 0.2 & $1.1 \pm 0.4$ & 2.3 \\
\hline \multirow[t]{5}{*}{ Heat-wave I } & Day 1 & 14.4 & $21.3 \pm 3.9$ & 27.1 & 0.5 & $1.7 \pm 0.7$ & 2.9 \\
\hline & Day 2 & 17.7 & $28.2 \pm 4.5$ & 33.7 & 1.1 & $2.8 \pm 1$ & 4.3 \\
\hline & Day 3 & 25.2 & $33.5 \pm 5$ & 42.8 & 1.8 & $4.1 \pm 1.7$ & 7.4 \\
\hline & Day 4 & 17.9 & $33.5 \pm 7$ & 42.2 & 1.2 & $4.2 \pm 1.9$ & 7.1 \\
\hline & Between & 15.7 & $20.7 \pm 3$ & 27 & 0.6 & $1.4 \pm 0.5$ & 2.6 \\
\hline \multirow[t]{5}{*}{ Heat-wave II } & Day1 & 17.0 & $26 \pm 4.8$ & 32.1 & 0.9 & $2.4 \pm 1$ & 3.9 \\
\hline & Day2 & 18.6 & $31.4 \pm 6.5$ & 40.2 & 1.1 & $3.7 \pm 1.7$ & 6.4 \\
\hline & Day3 & 25.8 & $34 \pm 5.4$ & 41.5 & 1.9 & $4.2 \pm 1.7$ & 6.9 \\
\hline & Day4 & 17.8 & $33.4 \pm 6.7$ & 42.2 & 0.9 & $3.9 \pm 1.8$ & 6.9 \\
\hline & After & 16.7 & $21.5 \pm 2.9$ & 26.5 & 0.6 & $1.4 \pm 0.5$ & 2.5 \\
\hline
\end{tabular}




\section{Gas exchange and BVOC emission analyses}

A custom-made, open chamber system, which has been previously described (Bamberger et al. 2017; Birami et al. 2018; Duarte et al. 2016), was used to automatically measure gas exchange and BVOC emissions from the shoots of the seedlings as follows. Randomly selected seedlings ( $n=4$ per treatment) were distributed spatially within each greenhouse compartment and their shoots were placed permanently in transparent cuvettes (Fig. S2a) made from acrylic glass tubes (6.65 L PMMA, Saalberg GmbH, Feldkirchen, Germany). Dismountable acrylic glass caps on the downward-facing side allowed to install the cuvette at the seedlings stem. The inside of the cuvettes had been coated with chemical inert foil FEP (fluorinated ethylene propylene, PTFE Spezialvertrieb, Stuhr, Germany), Small gaps between the stem and the cuvette were sealed with plastic putty (Teroson, Henkel Adhesives, Düsseldorf, Germany) to minimize gas leakage. A fan (412 FM, ebm-papst GmbH \& Co. KG, Mulfingen, Germany) guaranteed well-mixing of the air inside the cuvettes. To assess environmental conditions, each cuvette was equipped with a calibrated photo diode (G1118, Hamamatsu Photonics, Hamamatsu, Japan), a calibrated thermocouple (5SC-TTTI-36-2 M, Newport Electronics GmbH, Deckenpfronn, Germany).

The 18 cuvettes ( $n=4$ per treatment, $n=2$ for empty background) were measured continuously in an automated sequence as follows. After the distal cap of the cuvette had closed, a constant air stream (5 L F-201CZ-10 K, Bronkhorst, Ruurlo, the Netherlands) of clean air with on average $438 \pm 3 \mu \mathrm{mol} \mathrm{mol}^{-1}\left[\mathrm{CO}_{2}\right]$ and $6.5 \pm 0.1 \mathrm{mmol} \mathrm{mol}^{-1}\left[\mathrm{H}_{2} \mathrm{O}\right]$ was supplied for $10 \mathrm{~min}$. Zero air was generated by using an oil-free compressor (SLP-07E-S73, Anest Iwata, Yokohama, Japan) connected to an Ultra Zero Air generator (Ultra Zero Air GT, LNI Schmidlin SA, Geneva, Switzerland). $\mathrm{CO}_{2}$ was supplied from a gas cylinder and water vapour was added to the air stream via a nebulizing evaporation pump (LCU Liquid Calibration Unit, Ionicon, Innsbruck, Austria). The air supply was channeled through the main tubing made of stainless-steel tubing (3/8 inch Swagelok, Ohio, USA) coated with SilcoNert (Silco Tek GmbH, Bad Homburg, Germany) and gas flow to the cuvettes was controlled by two 2/2-way solenoid valves with a PTFE housing (0121A-6, 0-FFKM-TE, Bürkert, Ingelfingen, Germany) and PTFE tubing (ScanTube GmbH, Limburg, Germany). The detailed schematic of the measurement system can be found in Bamberger et al. (2017). For background measurements, two empty cuvettes (one each for the control and heat treatment) were measured during each measurement cycle and the recorded data were subtracted from the measurements containing seedlings (Birami et al. 2018).

Differences in $\left[\mathrm{CO}_{2}\right]$ and $\left[\mathrm{H}_{2} \mathrm{O}\right]$ between reference air and measurement air leaving the cuvettes were recorded differentially via a LI-7000 connected to a LI-840 (both LI-COR Inc., Lincoln, NE, USA). Net $\mathrm{CO}_{2}$ exchange ( $A_{\text {net }}$, $\left.R_{\text {dark }}\right)$, transpiration $(E)$ and stomatal conductance $\left(g_{\mathrm{s}}\right)$ were calculated as previously described in Birami et al. (2018). BVOC fluxes were measured with a high sensitivity protontransfer-reaction (quadrupole) mass spectrometer (PTR-(Q) MS, IONICON, Innsbruck, Austria). The PTR-MS was operating at standard conditions with a drift tube pressure of $2.3 \mathrm{mbar}$ and a drift tube voltage of $600 \mathrm{~V}$. More detailed settings of the instrument can be found in Bamberger et al. (2017). Volatile compounds were detected on protonated nominal mass ratios $\left(\mathrm{m} \mathrm{z}^{-1}\right)$ and quantified using a defined VOC mixture (14 components in nitrogen) of standard gas (\#24,182-650 IONICON, Innsbruck, Austria). PTR-MS calibration was performed at ambient humidity with a liquid calibration unit (LCU, IONICON, Innsbruck, Austria) on a weekly basis using a four-step calibration routine at mole fractions of 7.5, 5, 2.5 and $0 \mathrm{ppb}$.

The average sensitivity and limit of detection for each compound measured are given in Table 2. Since there was no representative for the GLV (e.g. z-3-hexenal) in our standard gas mixture, the sensitivity for $\mathrm{C}_{6} \mathrm{H}_{10} \mathrm{O}$ on $\mathrm{m} \mathrm{z}^{-1}$ 99 was estimated to be on average $3.15 \pm 0.13 \mathrm{ncps} \mathrm{ppb}^{-1}$, derived from the average sensitivity of xylene and toluene (the compound in the standard mixture being closest to $\mathrm{m}$ $z^{-1} 99$ to consider for the transmission efficiency of the quadrupole mass filter) multiplied by 0.33 , its known fractionation patterns (33\% on $\mathrm{m} \mathrm{z}^{-1}$ 99) (Fall et al. 1999). This was corrected for reaction rate coefficient $\mathrm{k}$ of $\mathrm{z}$-3-hexenal derived from Cappellin et al. (2012) for a $E: N$ ratio of 120 $\mathrm{Td}\left(\mathrm{k}_{\text {toluene }}=2.08 ; \mathrm{k}_{\mathrm{xyllene}}=2.27 ; \mathrm{k}_{\mathrm{z}-3 \text {-hexenal }}=3.25\right)$. The limit of detection for $\mathrm{m} \mathrm{z}^{-1} 99$ is hence not given. The sensitivity for $\mathrm{C}_{8} \mathrm{H}_{8} \mathrm{O}_{3} \mathrm{~m} \mathrm{z}^{-1} 153$ (on average $4.96 \pm 0.33 \mathrm{ncps} \mathrm{ppb}^{-1}$ ) was derived from a liquid calibration using a calibration mixture of methyl salicylate (A0366376, CAS: 119-36-8, ACROS Organics, New Jersey, USA) in $\mathrm{H}_{2} \mathrm{O}$ (Type 1, MilliQ ${ }^{\circledR}$ Direct8, Merck KGaA, Darmstadt, Germany) (7.8 ppb, $5.2 \mathrm{ppb}, 2.6 \mathrm{ppb}, 1.3 \mathrm{ppb}$ and $0 \mathrm{ppb}$ ). Isoprene could not be distinguished from 2-methyl-3-butene-2-ol (MBO) with our method, hence we did not investigate this compound in detail and address it as "isoprene + MBO". Ethanol could not be detected in satisfactory quality and was hence not further interpreted (see limit of detection Table 2).

To ensure that concentrations of volatiles represented steady-state conditions, emissions were calculated from the last $360 \mathrm{~s}$ per $10 \mathrm{~min}$ measurement $\left(c_{\text {out, }} c_{0}\right)$, given that the stability quality criteria were full-filled and backflow from the cuvettes was $>0.3 \mathrm{~L} \mathrm{~min}^{-1}$. Linear regression data were used to assess stability of the signal using an upper boundary for the regression slope $\leq 3\left(\frac{\sqrt{\langle s\rangle}}{\delta t}\right)$, where $\langle s\rangle$ is the average signal from the analyzer in cps and $\delta t$ is the length of the time interval used for averaging in s. Note: the term $\sqrt{\langle s\rangle}$ is 
Table 2 Sensitivity $( \pm 1 \mathrm{SD})$ and limit of detection of all measured compounds in the calibration standard averaged over all weekly calibration cycles. Sensitivity is defined as normalized counts per second per ppb of primary ions $\mathrm{H}_{3} \mathrm{O}^{+}$ and $\mathrm{H}_{2} \mathrm{OH}_{3} \mathrm{O}^{+}$within volume, ncps ppbv ${ }^{-1}$

\begin{tabular}{llll}
\hline Compound & Mass fragment & $\begin{array}{l}\text { Sensitivity } \\
\text { ncps ppbv }\end{array}$ & $\begin{array}{l}\text { Limit of detection } \\
\text { ppbv }\end{array}$ \\
\hline Methanol* $^{*}$ & 33 & $9.55 \pm 0.35$ & $0.35 \pm 0.05$ \\
Acetaldehyde* $^{*}$ & 45 & $14.57 \pm 0.63$ & $0.1 \pm 0.04$ \\
Ethanol & 47 & $0.80 \pm 0.11$ & $3.52 \pm 0.56$ \\
Acetone* & 59 & $15.77 \pm 1.12$ & $0.06 \pm 0.02$ \\
Isoprene (MBO's) & 69 & $5.10 \pm 0.46$ & $0.09 \pm 0.03$ \\
Monoterpene fragments & 81 & $5.25 \pm 0.76$ & $0.07 \pm 0.02$ \\
Toluene & 93 & $6.66 \pm 0.89$ & $0.08 \pm 0.02$ \\
Hexenal & 99 & $3.15 \pm 0.13$ & $\mathrm{NaN}$ \\
O-Xylene & 107 & $6.11 \pm 0.98$ & $0.11 \pm 0.04$ \\
Monoterpene $(\alpha-$ pinene) & & $1.65 \pm 0.37$ & $0.13 \pm 0.04$ \\
Methyl Salicylate* & 137 & $4.96 \pm 0.33$ & $0.08 \pm 0.02$ \\
\hline
\end{tabular}

For calculation of the apparent fluxes, linear interpolation within two calibration cycles was used, hence the table presents a guideline example for the procedure. BVOC analysed are highlighted with an asterisks. BVOCs not present in the calibration standard (\#24,182-650 IONICON) are in italic and their respective sensitivities were calculated as described in the methods. Note that $\mathrm{m} 81$ was not used in the analyses given by the Poison-Noise of the analyzer. The fluxes of volatile compounds $\left(E_{\nu}\right.$ in nmol m$\left.{ }^{-2} \mathrm{~s}^{-1}\right)$ were calculated from the concentration differences of air leaving the cuvette $c_{\text {out }}$ and the concentrations leaving an empty chamber $c_{0}$ (Niinemets et al. 2011) as follows

$E_{v}=\left(c_{\text {out }}-c_{\mathrm{O}}\right) \frac{f}{l_{\mathrm{a}}}$

with the flowrate $f$ in mol $\mathrm{s}^{-1}$ to each cuvette and the projected leaf area of the seedlings $l_{\mathrm{a}}$ in $\mathrm{m}^{2}$ (Birami et al. 2018). The projected leaf area was derived from photographs taken during the experiment and estimated through needle color thresholds (Fig. S2b). The projected area was linearly extrapolated.

\section{Endogenous monoterpene and sesquiterpene measurements}

To determine the impacts of two consecutive heatwaves on the pools of endogenous MT and SQT, six additional seedlings per treatment were sampled between 1 and $3 \mathrm{pm}$ on the last day of the second heatwave. The lower part of the seedlings' stem was removed and the samples (mainly needles and twigs) were immediately frozen in liquid nitrogen and ground in porcelain mortars to a fine powder and stored at $-80^{\circ} \mathrm{C}$ until further processing. MT and SQT were analyzed similarly as done before (Ghirardo et al. 2010; Vanhatalo et al. 2018). One $\mathrm{mL}$ of hexane (SupraSolv for GCMS, Merck Chemicals GmbH, Germany) containing 859.3 pmol $\mu \mathrm{L}^{-1}$ of $\delta$-2-carene as the internal standard was added as a solvent to $50 \mathrm{mg}$ of the ground and still frozen plant material in $2 \mathrm{~mL}$ gas-tight amber glass vials (Merck) and extracted at $4{ }^{\circ} \mathrm{C}$ for $3 \mathrm{~h}$ in continuous shaking. Samples were incubated overnight at $5{ }^{\circ} \mathrm{C}$, and the supernatant was transferred into a new $2 \mathrm{~mL}$ glass vial using a $1 \mathrm{~mL}$ gas-tight syringe (Hamilton). Finally, $1 \mu \mathrm{L}$ per sample was analyzed by thermo-desorption (TD) gas chromatography mass spectrometry (GC-MS) (Ghirardo et al. 2012). The TD-GC-MS was run and GC-MS data were evaluated as reported elsewhere (Ghirardo et al. 2020). Each sample was analyzed in triplicates and medians were taken from technical replicates. Final endogenous MT or SQT content was related to dried plant material, by weighing for each individual sample, a subsample of the freshly ground and frozen plant powder before and after oven drying at $60{ }^{\circ} \mathrm{C}$ for $48 \mathrm{~h}$.

\section{Data analyses and statistics}

To visualize how BVOC emissions vary across treatments, we performed a canonical correspondence analysis (CCA, (TerBraak, Cajo J. F. 1986)) between normalized emission rates, treatment and experimental period. CCA allows to test for the significance of each of the ordination axis, as well as for the influence of factors and cofactors. Monte Carlo permutations (here $n=1000$ ) were performed to assess if the variability explained by the model is higher than the variability explained by a randomly generated set of variables (Oksanen 2011). BVOC emission rates were daily-averages that were normalized to pre-stress conditions per individual seedling to reduce the effect of biologic variance. Two separated analyses were performed on the surviving seedlings only (excluding $\mathrm{m} 81, \mathrm{~m} 93, \mathrm{~m} 107$, see Table 2): (i) pre-stress vs. first heatwave, and (ii) first heatwave vs. second heatwave. CCA analyses were done using the "Vegan" package, V2.5-6 (Oksanen et al. 2013).

Linear mixed effect models (lme, R packages: "Ime4", "nlme" and "MuMIn") were used to test for dependencies 
of BVOC emissions, gas exchange on rSWC or temperature and treatment (fixed effects) Seedling was considered as a random effect. Temporal auto-correlation was accounted for by including a first-order Auto-Regressive model in the lme (Box et al. 2016). AICc criteria (Akaike information criterion corrected for small sample size) was used to select for the most parsimonious model (i.e., best model with as few predictive variables as possible), with a threshold for acceptation of 2, based on (Burnham and Anderson 2004). When the most parsimonious model was identified, a pseudo $\mathrm{R}^{2}$ was calculated both for the fixed and the combined fixed and random effects and confidence intervals (CI) given (Nakagawa et al. 2013). Normality of the residuals and homoscedasticity were visually inspected.

During the course of the experiment, three of the continuously measured seedlings (BVOC, gas exchange) in the heatdrought and one in the heat-treatment died due to overheating (Birami et al. 2018). Hence, treatment-specific analyses of BVOC emissions were done using the surviving seedlings only (heat-drought $n=1$, heat $n=3$, drought $n=4$, control $n=4)$. The impact of dying and death on BVOC emissions was analyzed by grouping the heat and heat-drought seedlings into surviving $(n=4)$ and dying $(n=4)$. In case to overcome tree-specific differences in absolute emission rates, we normalized the data to a tree-specific median derived from before stress-conditions (110-114 DOY), which was for instance done when analyzing mortality responses. Treatment-averaged absolute emission rates per experimental

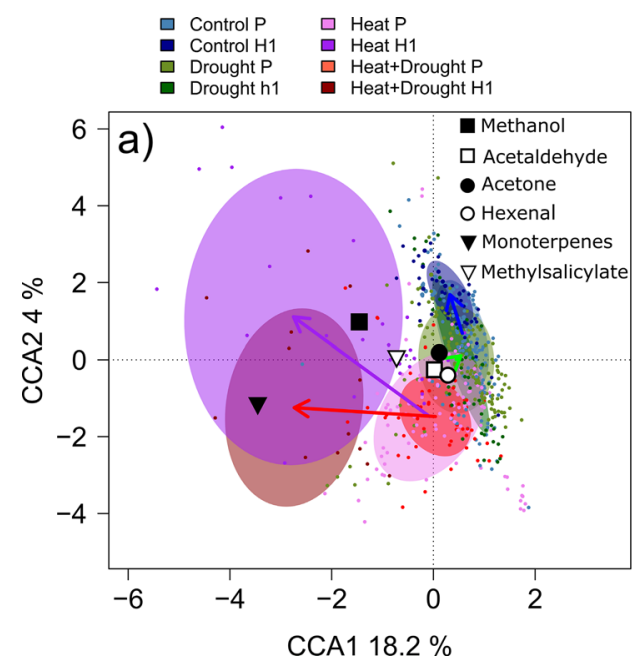

Fig. 2 a Pre-stress and treatment-specific stress responses of six selected BVOC emissions of the surviving Aleppo pine seedlings (methanol, acetaldehyde, acetone, hexenal, monoterpenes, methyl salicylate). Shown as canonical correspondence analysis (CCA; for details see Data analysis and statistics section) to test for different responses of BVOC emissions of control (blue), drought (green), heat (magenta) and heat-drought (red) seedlings for pre-stress (P, lighter color) and first heatwave (H1, darker, corresponding color) condi- period can be found in the Supplement (Table S4) and are given in Fig. 4.

\section{Results}

\section{BVOC emissions during heatwaves and drought}

Because extreme temperatures were reached during the heatwaves, three of the continuously monitored seedlings in the heat-drought and one in the heat treatment died. Because the dying seedlings experienced different BVOC emissions, we concentrate here on the surviving seedlings first. The emission patterns of the Aleppo pine seedlings in the heat $n=3$ and heat-drought $(n=1)$ treatment responded similar to heat stress (Fig. 2a). High temperatures predominantly increased emissions of MT and methanol compared to prestress conditions. Further, we found the emissions of methyl salicylate and hexenal to increase modestly in response to the heatwave. Interestingly, the drought treatment alone did at first not result in a distinct BVOC response (Fig. 2a), only with the progression of the experiment and increasing soil drought (Fig. 2b).

\section{Sensitivity of acetone emissions to soil water availability}

Here we focus on the impact of drought stress on BVOC emissions and found one distinct response. We found acetone

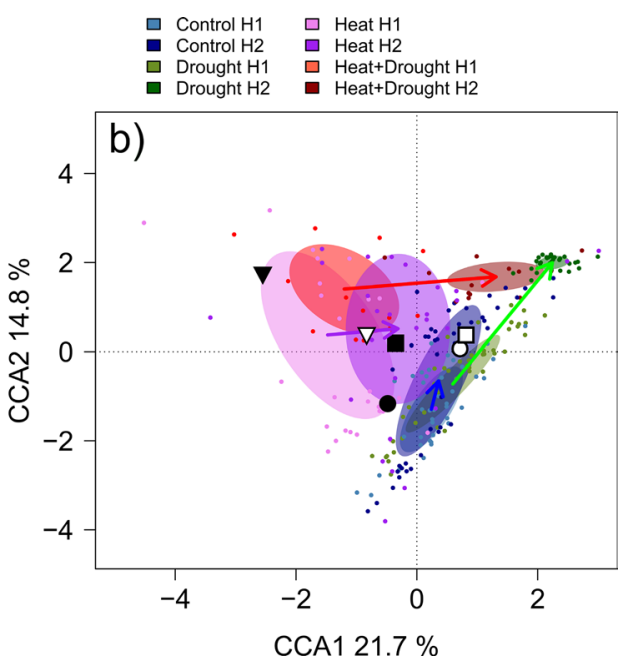

tions. b Comparison of treatment-specific BVOC emission responses between the first (H1) and the second heatwave (H2). Colored areas depict the $95 \%$ confidence interval ellipsoid per treatment and period. Dependencies between the compounds (loadings) and the canonical variates (treatment) are shown for methanol, acetaldehyde, acetone, hexenal, monoterpenes and methyl salicylate. Note that emissions are only given for the surviving seedlings (heat: $n=3$, heat-drought: $n=1$, control: $n=4$, drought: $n=4$ ) 
to co-vary with soil water content (Fig. 3) and its emissions to decrease at low water availability (see also Fig. 2b). We found that a $10 \%$ decrease in rSWC results in a $10 \%(5-14 \%$ $\mathrm{CI}$; derived from lme) decrease in acetone emissions compared to well-watered conditions. Furthermore, both $\mathrm{g}_{\mathrm{s}}$ and transpiration were included in the lme model, with acetone emissions being better explained by transpiration (pseudo$\left.\mathrm{R}_{\text {fixed }}^{2}=0.39\right)$ than by $\mathrm{g}_{\mathrm{s}}\left(\right.$ pseudo- $\left.\mathrm{R}_{\text {fixed }}^{2}=0.1\right)$. Hence, changes in acetone emission were most likely caused by soil water availability and tree water flux. As we observed that acetone emissions from our potting-medium were negligible ( $<3 \%$ of average acetone emission rates from well-watered seedlings; data not shown), acetone was most likely produced in the root tissues and transported to the shoots via the transpiration stream. No other BVOC showed a clear drought response (Fig. 2; Table S4).

\section{Impact of repeated heatwaves on gas exchange and BVOC emissions}

We investigated the impact of repeating heatwaves on the temperature response of BVOC emissions and gas exchange in the surviving Aleppo pine seedlings (Fig. 4). $A_{\text {net }}$ peaked at about $21.5^{\circ} \mathrm{C}$ when VPD had reached $1.8 \mathrm{kPa}$ (increase in temperature exponentially increased VPD following $\left(\mathrm{VPD}=\exp (0.066(\mathrm{~T})-0.85), \mathrm{R}^{2}=0.94\right.$ of log-transformed function, Fig. S3b), while $g_{\mathrm{s}}$ decreased to tightly regulate seedling water loss. In contrast, all observed BVOC emissions, except acetone (Fig. 4h), increased with increasing temperatures exponentially (Fig. $4 \mathrm{c}-\mathrm{g}$ ). It is notable that

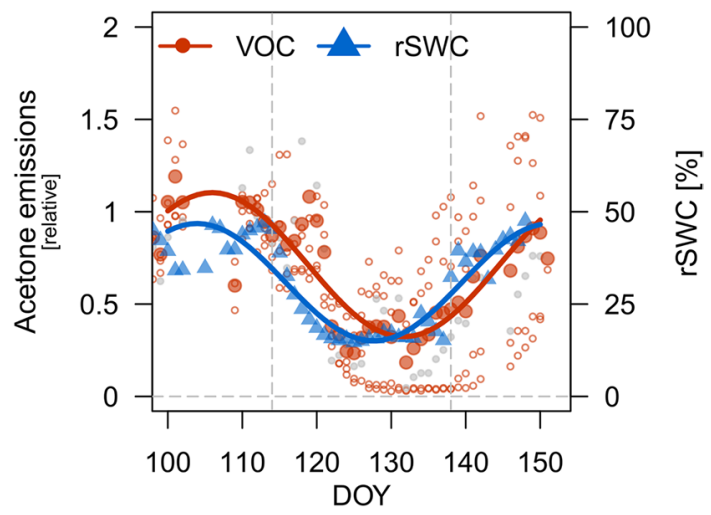

Fig. 3 Dynamics of daily-averaged relative soil water content (rSWC [\%], blue triangles) and acetone emissions during drying and rewetting shown for the drought $(n=4$; open red circles) and heatdrought ( $n=1$; grey solid circles) treatment. Acetone emissions are given relative to the pre-stress for measurements when $P A R \geq 100$ (open filled red circles present daily-averages combining both treatments). Colored lines are added to visualize the overall development and represent a trigonometric best-fit using non-linear regression: $\alpha^{*} \sin \left(\omega^{*}(\mathrm{x}+\phi)\right)+\mathrm{C}$ with $\mathrm{x}$ being DOY and starting parameters $(\alpha$, $\omega, \phi, C)$ although $g_{\mathrm{s}}$ decreased in response to the heatwaves, $E$ (Fig. S3a) followed an exponential temperature response with slightly lower transpiration rates during the second heatwave.

MT and methanol represented the highest emission rates during heat exposure (Fig. $4 \mathrm{c}$ and d). However, an altered temperature relationship became most obvious for MT and MeSa during the second heatwave after exposure to the first heatwave. To test for differences in responses of emissions to temperature, separate lme were computed for MT and MeSa for the first- (H1) and the second heatwave (H2). Although the intercepts of the most parsimonious lme did not differ (overlapping 95\% CI, implying similar response amplitudes), the response slope to temperature was reduced markedly (MT, H1: 0.26 [0.21-0.31 CI], H2:0.11 [0.08-0.13 $\mathrm{CI}] ; \mathrm{MeSa}, \mathrm{H} 1: 0.001$ [0.0009-0.0013 CI], H2:0.0006 [0.0004-0.0008 CI]), which shows that the same temperature does not induce the same emission signal during repeated stress. Methanol, hexenal, and acetaldehyde did not show a change in heat response between heatwaves. Acetone did not show clear temperature dependencies (Fig. 4h).

We further studied the endogenous MT pools to test the hypothesis that changes in emission patterns might be a consequence of the depletion of MT storages. Total endogenous MT pools did not decrease in plants exposed to two heatwaves, compared to seedlings grown under control conditions (Fig. 5a). The same picture emerged when calculating the total MT pool per average seedling (heat: $148 \pm 30 \mathrm{SE}$ $\mathrm{mg}$, control: $173 \pm 40 \mathrm{SE} \mathrm{mg}$ based on the molar weight of a-pinene of $136.2 \mathrm{~g} \mathrm{~mol}^{-1}$ ). This was in contrast to the cumulative MT emissions during the two heatwaves (DOY 114-131) which summed up to $28.1 \pm 4.4 \mathrm{SE} \mathrm{mg}$ (Table S2), and would hence account for a 19.7 \pm 1.2 SE \% decrease of the total pool (as derived above). Considering specific compounds, we did not observe a significant impact of heat stress on any of the 14 MT measured (Table S2). Notably, the overall content of stress-induced SQT compounds (sum of 14) tended to increase compared to the control seedlings $(P=0.07$, TukeyHSD, Fig. 5b).

\section{Impacts of tree mortality on BVOC emissions}

The stress intensity, in particular in the combination of heat stress with drought, resulted in pronounced seedling mortality due to overheating. This overheating was more pronounced in the heat-drought treatment due to the lack of evaporative cooling and needle temperatures of $47{ }^{\circ} \mathrm{C}$ were reached (Birami et al. 2018). As a consequence some of the seedlings that were constantly monitored for BVOC emissions died: one in the heat treatment and three in the heat-drought treatment. The first indication for a reduced vitality of the seedlings can be seen in net photosynthesis $\left(A_{\text {net }}\right)$ and transpiration to reach zero between the two 
Fig. 4 Differences in temperature responses of gas exchange and BVOC emissions during the first (filled circles, light green) and second heatwave (triangles, lilac) of the surviving Aleppo pine seedlings in the heat treatment $(n=3)$. Data are given for PAR $\geq 100 \mu \mathrm{mol} \mathrm{m}^{-2} \mathrm{~s}^{-1}$ including several days before heatwave initiation. a Temperature $(\mathrm{T})$ responses of photosynthesis $\left(\mathrm{A}_{\text {net }}\right)$ and $\mathbf{b}$ stomatal conductance $\left(\mathrm{g}_{\mathrm{s}}\right.$, ) are shown and the regression lines depict second order exponential functions $\left(\exp \left(\mathrm{a}+\mathrm{b}(\mathrm{T})+\mathrm{c}(\mathrm{T})^{2}\right)\right)$. c The temperature responses of monoterpenes, $\mathbf{d}$ methanol, e methyl salicylate, $\mathbf{f}$ hexenal, $\mathbf{g}$ acetaldehyde and $\mathbf{h}$ acetone are depicted by exponential functions $(\exp (b(T)+c)$. Shaded areas depict the $95 \%$ confidence intervals of the fitted functions. Note that VPD increased exponentially with temperature: $\mathrm{VPD}=\exp (0.66(\mathrm{~T})-0.85)$ $\left(\mathrm{R}^{2}=0.94\right.$ of log-transformed function). The transparent data points are single measurements, while the solid symbols are binaverages $\left(10-50^{\circ} \mathrm{C}\right.$ by $\left.10^{\circ} \mathrm{C}\right)$ and shown for clarity
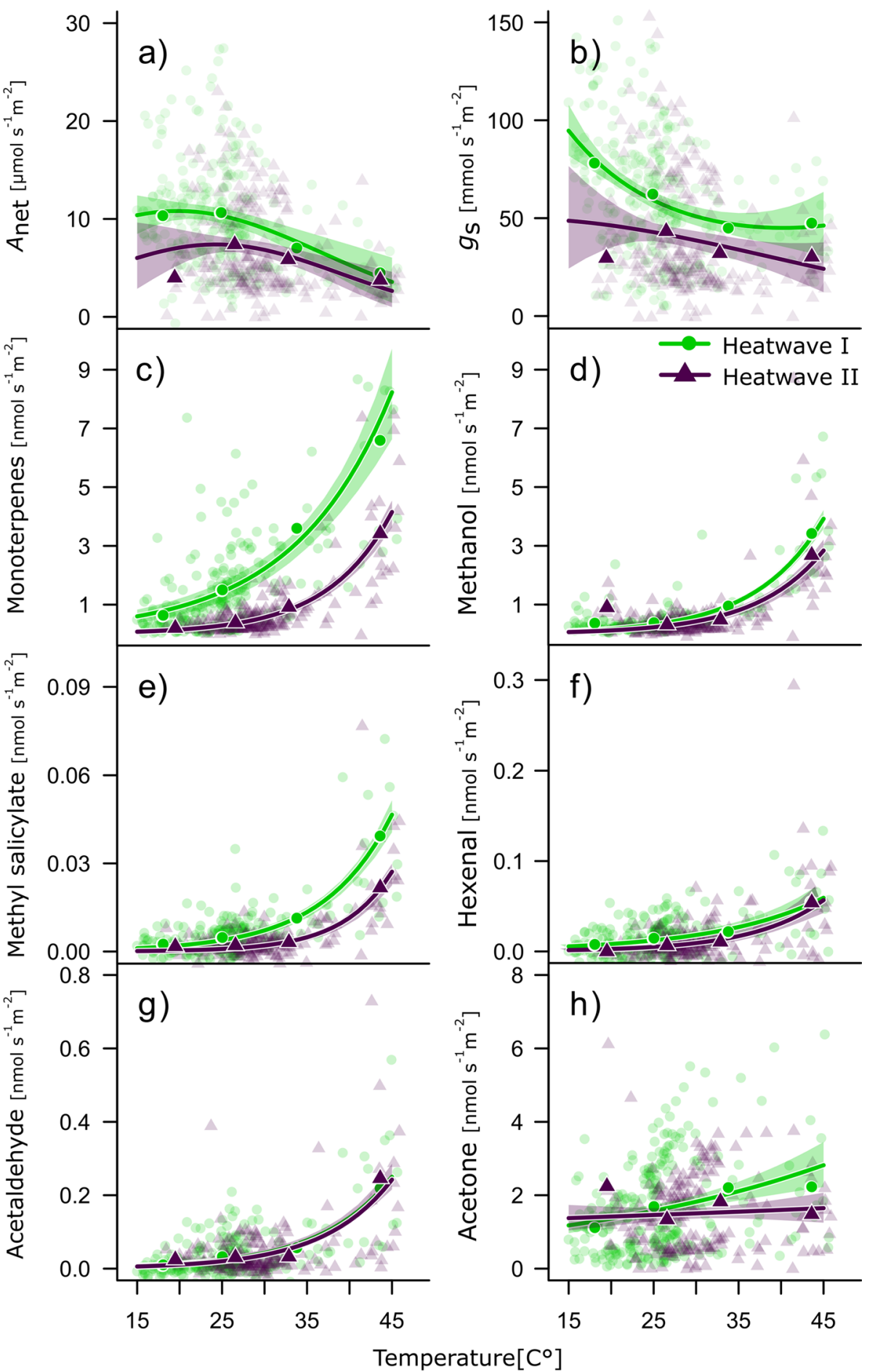

heatwaves (Fig. 6; horizontal grey bars) (Birami et al. 2018). However, we found clear differences in the emission rates between surviving and dying seedlings already much earlier. We found particularly strong responses in acetaldehyde (Fig. 6d, TukeyHSD: P $\leq 0.05$ ) and MT (Fig. 6b, TukeyHSD: $\mathrm{P} \leq 0.05)$ emissions, which were much higher during the first heatwave in the later dying compared to the surviving seedlings. Interestingly, these emissions also remained elevated during the first recovery period (between heatwaves). For methanol (Fig. 6a) and MeSa (Fig. 6c) emissions we found similar responses, albeit with a shift to increased emissions of the dying seedlings during the second heatwave. A clear indication for the death of the seedlings was the moment when dark respiration ceased (Fig. 6, black bar represents when shoot respiration reached zero). This was directly after the end of the second heatwave. Further, analysis of shoot 


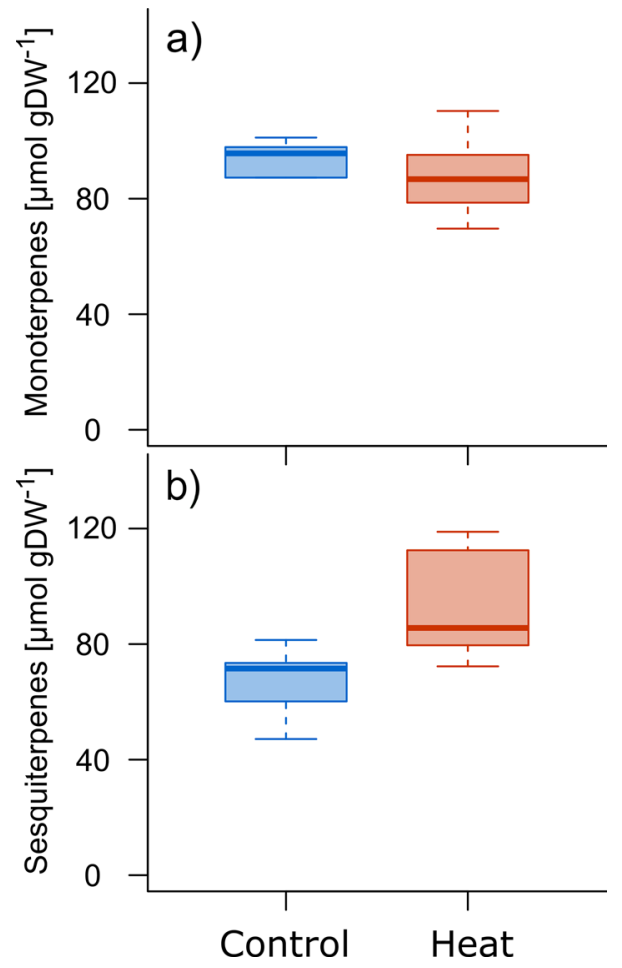

Fig. 5 Concentrations of $\mathbf{a}$ endogenous monoterpenes and $\mathbf{b}$ sesquiterpenes in green shoots of control and heat-treated Aleppo pine seedlings sampled at the last day of the second heatwave $(n=6$ per treatment). The box plots depict the median, lower, and upper quartiles (25th-75th percentiles)

water content at the end of the experiment confirmed the differentiation in mortality and surviving seedlings. Surviving seedlings had an absolute shoot water content of $64.2 \pm 2 \%$, while the water content in the dead seedlings averaged at $24.2 \pm 13 \%$ (Birami et al. 2018).

\section{Discussion}

\section{Impacts of two consecutive heatwaves on BVOC emissions and gas exchange}

We found a strong stimulation of BVOC emissions during two consecutive heatwaves. Monoterpene, methanol, MeSa, hexenal, and acetaldehyde emissions increased exponentially with increasing temperatures. In particular, MT emissions showed a sharp increase between 30 and $43{ }^{\circ} \mathrm{C}$. In contrast, acetone was insensitive to changes in temperature but responded to soil water availability (see below).

Monoterpene emissions are known to respond strongly to temperature increase by release from specific storage pools depending on diffusion parameters and volatility (Kleist et al. 2012; Peñuelas and Llusià 1999; Staudt et al.
2017), including leaves and stems (Vanhatalo et al. 2020). On the other hand, MT emissions of pines have been shown to originate to more than $50 \%$ directly from photosynthetic products under stressed conditions (Ghirardo et al. 2010; Taipale et al. 2011). In our experiment, the response of MT emissions of surviving seedlings to temperature was considerably weaker during the second heatwave (emission rates at a specific temperature were about $50 \%$, and maximum emission tended to be lower than during the first heatwave). With this respect, the results from our study agree well with previous studies on MT and MeSa emissions in Scots pine (Kleist et al. 2012), which reported a down-regulation of emissions during consecutive heatwaves. Such a response may indicate depletion of storages or could point towards metabolic adjustments of volatile biosynthesis.

The MT storage in plants, formed by specialized organs such as resin ducts, is typically large. In our investigations, we have found the monoterpene content to be $1.3 \%$ of dry weight in shoot biomass of Aleppo pine seedlings (Table S5), similar to those of dried needle biomass of Scots pine $(0.8 \%)$ reported by Vanhatalo et al. (2018). Usually, a depletion of such a large storage is unlikely to happen in short time (few days), as it did not occur in two years old needles after MT emissions of an entire season (Vanhatalo et al. 2018). However, the depletion of MT storages has been proposed as a possible mechanism if plant tissue is exposed to high temperatures over a longer period (days to months) (Schurgers et al. 2009) and are shown to be reduced after 4 years of heat treatment $\left(+3.5^{\circ} \mathrm{C}\right)$ compared to nontreated Douglas fir saplings (Snow et al. 2003). Our measurements showed that the overall MT pools remained unaffected, although the cumulative MT emissions during both heatwaves were expected to deplete approximately $20 \%$ of the total endogenous MT pool of the heat-treated seedlings (Table S5). This implies that MT's are de novo produced and directly released during heatwaves. Possibly, de novo MT production was impaired along with photosynthesis during the first heatwave and this caused lower MT emission during the second heatwave, compared to the first one. Although older investigations could not find a significant contribution of emission from de novo biosynthesis for Aleppo pine (Peñuelas and Llusià 1999), more recent studies indicate that the contribution could be around 50\% (Llusia et al. 2016) and might be as high as $70 \%$ in 3-4-year-old trees (Staudt et al. 2017). It has also been shown that MT biosynthesis, in general, is sensitive to stress which also negatively affects $A_{\text {net }}$-such as drought-(Kleist et al. 2012; Lüpke et al. 2017) since the plastidic intermediate for the terpenoid synthesis is closely connected to photosynthesis (Ghirardo et al. 2014). Another explanation for the observed burst of MT during the heatwaves may be that those emissions originated from MT pools of non-specialized structures such as the lipid phase of cellular compartments and membranes 
Fig. 6 Responses of a methanol, b monoterpene, c methyl salicylate and $\mathbf{d}$ acetaldehyde emissions during seedling mortality. The emission data are shown relative to pre-stress derived from daily-averages (for measurements when $P A R \geq 100$ ) per seedling, separated in surviving (green, $n=4$; including 3 seedlings from the heat and 1 seedlings from the heat-drought treatment) and dying (white, $n=4$; including 1 seedlings from the heat and 3 seedlings from the heat-drought treatment). The two heatwaves are highlighted by a solid colored background (DOY 118-121; 128-131). Horizontal grey bars mark the time course on when either daily-averaged transpiration or net photosynthesis or both of the dying seedlings reached zero. The time when dark respiration reached zero and seedlings were clearly dead is indicated by the black horizontal bars. Daily-averaged emission data was derived for measurements of PAR $\geq 100$

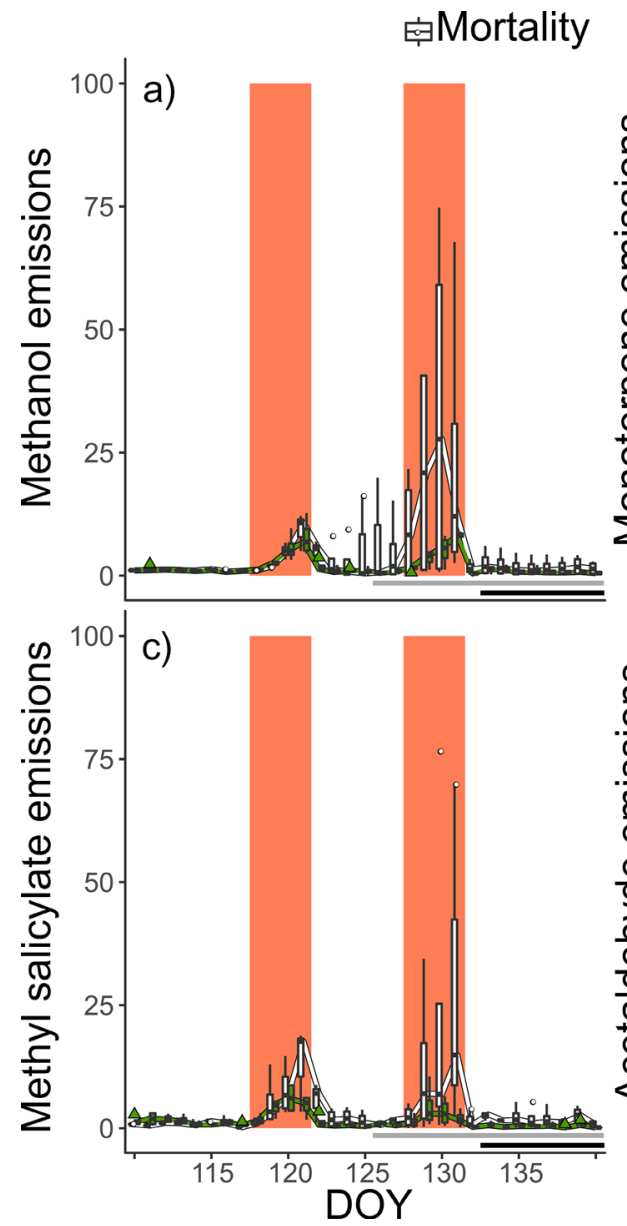

(Joensuu et al. 2016; Nagegowda 2010; Yazaki et al. 2017). Overall their amount is small compared to the pool in specific storage tissue such as resin ducts (Ormeño et al. 2011), but might face less diffusive resistance and can readily enter the gas phase. Following this, intramembrane or cuticular MT are likely to be primarily released during the first heatwave and were not refilled before the second heatwave, contributing to the overall smaller emission rates. Hence we have no information about the actual compartmentation of the endogenous MT, de novo synthesized MT may have prevented total pool depletion and a delayed refilling of the non-specialized pools may have reduced the emissions during the second heatwave. As reported in poplar, membrane collapse caused by severe heat stress may as well cause such a burst of several BVOC, including MT (Behnke et al. 2013).

Methyl salicylate emissions, which are known to increase under stress in many tree species (Filella et al. 2006; Joó et al. 2011), also showed an altered temperature-response during the second heatwave. While MeSa has been shown to be released under biotic stress, it has also been related to drought (Karl et al. 2008; Scott et al. 2019). As a signaltransmitting metabolite, MeSa is freshly mobilized from precursor molecules (Heil and Ton 2008). The reduced temperature-response of emissions during the second heatwave might thus indicate a suppression of enzymatic activity and might support the hypothesis that, at least, parts of the observed MT burst are caused by de novo production. Suppression of MeSa mobilization from salicylic acid at high temperatures has been previously reported (Shulaev et al. 1997), while in a study on Arabidopsis thaliana thermal pre-treatment $\left(38{ }^{\circ} \mathrm{C}\right)$ induced salicylic acid accumulation (non-volatile form of $\mathrm{MeSa}$ ) that caused thermotolerance of the plants at $47^{\circ} \mathrm{C}$ (Clarke et al. 2004).

Overall, we could show that consecutive heatwaves alter the temperature-sensitivity of MT and MeSa emissions and that these changes are not related to any declines of pools in specific structures. Instead, the decrease in responsiveness seems strongly related to reduced metabolic activity, possibly due to reduced enzyme production or increased damage of metabolic production chains.

\section{Impact of drought on BVOC emissions}

Previously observed responses of BVOC emissions to water availability are inconclusive in the case of Aleppo pine. Some studies report MT emissions to decrease with 
drought (Blanch et al. 2007; Llusia et al. 2016), while others report increases (Llusià et al. 2008). Overall, the emission response might particularly depend on the severity and duration of drought, increasing at first under mild drought but decreasing with drought progression (Ormeño et al. 2007). In our experiments, we could not observe drought-specific responses of MT emissions, which, however, might be due to a physiological adjustment that reduced MT emissions already under non-stressed conditions. The same response has been shown for mature trees at the same site, which is different to stands under less extreme conditions (Llusia et al. 2016), indicating that the adjustment origins from genetic rather than morphological changes.

On the other hand, we found that reduced acetone emissions were indicative for drought conditions. Acetone represented one of the most abundant volatile compounds emitted. Acetone probably originated from the root tissue and was then transported to the shoots of the seedlings as long as soil water availability is sufficient. This is similar to what has been reported for Aleppo pine stands (Filella et al. 2009) and is also supported by studies demonstrating that the emissions of water soluble short-chained compounds depends on $E$ (Rissanen et al. 2018). Acetone is the smallest ketone of the anoxic fermentation chain derived from Acetyl-CoA that is metabolized either from pyruvate or fatty-acid oxidation (Fall 2003; Grote et al. 2019) and is indeed easily water-soluble. It was found to be an indicator for flooding in the roots of trees from the Amazonian floodplains (BrachoNunez et al. 2012). In temperate and boreal forests, acetone emissions have been generally related to water availability (Janson and Serves 2001; Shao and Wildt 2002). Acetone is thus a likely candidate for an indicator of drought-stress, particularly for coniferous forests. This largely supports our first hypothesis that responses of specific BVOC emissions can be directly linked to the type of stress. Where MT emissions were found to be strongly induced by heat stress, acetone emissions were found to decline under drought.

\section{Methanol as an indicator for lethal stress}

At the end of the experiment, four of the seedlings constantly monitored for gas exchange and BVOC emission died (heat: $n=1$; heat-drought: $n=3$ ). Mortality was more pronounced in the group of heat-drought-stressed seedlings, possibly due to damages from higher leaf temperatures caused by reduced evaporative cooling $\left(>47^{\circ} \mathrm{C}\right.$, (Birami et al. 2018)). While the exact time of death is challenging to determine, gas exchange data show that $A_{\text {net }}$ and $E$ reached zero between the two heatwaves (Table S3) and that shortly afterwards also dark respiration stopped, indicating that shoots became metabolically inactive. We found an increase of methanol emission in dying (but not in surviving) seedlings one day before this occurrence, while otherwise the emission rate was relatively stable as highlighted before (Seco et al. 2015). To the best of our knowledge, it is the first time that changes in emission patterns of BVOCs were directly linked to heatinduced mortality.

It has been commonly observed that emission of green leave volatiles and oxygenated VOCs such as methanol increase during heat stress (Kleist et al. 2012). This has been particularly reported under high temperatures and limited water supply (Filella et al. 2009; Jardine et al. 2015). Methanol is produced in considerable amounts during cell wall formation, released by pectin methylesterases (PMEs), allowing to adjust the rigidity of the cell walls. Heat stress $\left(35-65^{\circ} \mathrm{C}\right)$ in turn, was reported to activate apoplastic PMEs (Wu et al. 2018). While methanol is being cleaved from pectine, $\mathrm{Ca}^{2+}$ is being released, which passes the cell membrane and starts a cascade of intracellular stress signals (Dorokhov et al. 2018; Wu et al. 2018). Thus, excess in methanol production can be a sign of active growth processes, or be the consequence of the demethylation of several methylated compounds (e.g. DNA, RNA, histones, and other proteins) occurring after cell damage and oxidative stress as it was reviewed by Kim et al. (2015). The co-occurrence of a substantial increase in the emissions of lipoxygenase products such as hexenal (Fig S3) with high methanol fluxes (Fig. 6a), provides a strong indication that methanol emissions were related to cell and membrane damages. Indeed, after membrane disruption, lipoxygenase products are formed when the fatty acid substrates trapped in the cell membrane get in contact with cytosolic enzymes. In turn, the concomitant but stronger methanol emissions might be a reliable indicator of lethal heat dosage (Turan et al. 2019).

\section{Excessive MT and acetaldehyde emissions anticipate higher sensitivity to stress}

Monoterpene and acetaldehyde emissions of seedlings that died after the first heatwave were distinct from surviving seedlings, albeit photosynthetic rates were not showing apparent differences between dying and surviving individuals until the first day of stress release (Table S3, S4 (Birami et al. 2018)). Susceptible seedlings showed a tendency of higher emissions in MeSa, $69 \mathrm{~m} \mathrm{z}-1$ (which is an unknown compound that could either be isoprene or MBO, Fig. S3a), and hexenal (Fig. S3b).

$\mathrm{MeSa}$ and hexenal have been previously depicted as stress sensing and stress signaling molecules (Tawfik et al. 2017; Wu et al. 2018). Acetaldehyde emissions, however, were found to be closely related to stomatal conductance in Aleppo pine (Filella et al. 2009; Seco et al. 2008). This is in contrast to our results, where increasing temperatures decreased stomatal conductance both in surviving and dying seedlings, while acetaldehyde emission rates increased independent of $g_{\mathrm{s}}$. Increased acetaldehyde 
production may result from a possible pyruvate substrate overflow mechanism during times of sudden changes in light intensity, when downstream processes of carbohydrate reduction are limited (Karl et al. 2002). Carbohydrate metabolism can also be limited by temperature stress, which is supported by similarities between the metabolic response to anoxia and high temperatures, both inducing anoxic fermentation pathways (Pucciariello et al. 2012) that eventually result in acetaldehyde formation (Kreuzwieser et al. 1999). Formation and production not necessarily result in immediate emission, nonetheless, acetaldehyde is released when terminal cell damage occurs (Behnke et al. 2013; Fall et al. 1999; Loreto et al. 2006; Portillo-Estrada et al. 2015; Turan et al. 2019). Interestingly, also the surviving seedlings showed a higher emission rate of acetaldehyde at the end of the second heatwave, indicating (i) that some damages occurred also in the surviving seedlings which might have been fatal in a third heatwave, and (ii) that acetaldehyde might be a better sensitivity indicator than MT alone.

Still, it is difficult to explain why the dying seedlings had higher acetaldehyde and MT emissions before and after actual mortality happened (Fig. 6b and d) although similar observations have been made on different plants or tissues. For example, high emissions of acetaldehyde and other oxygenated VOCs have been reported during the process of grass drying (Gouw et al. 1999). Also, active dehydrogenases that might produce acetaldehyde have been found in dry heartwood (Tohmura et al. 2012) and during industrial drying of pinewood (McDonald et al. 2002). In all cases, it was assumed that acetaldehyde emissions were caused by enzymatic or microbial remnant activity or oxidative decomposition of cellulose i.e., resin components. Regarding the increased MT emissions, it should be considered that the absolute magnitude of emissions from the dying seedlings $(55.2 \pm 21.7 \mathrm{mg})$ doubled the cumulative emissions from surviving heat-treated seedlings $(28.1 \pm 4.4 \mathrm{mg})$. This would relate to an approximate loss of about $35 \%$ in relation to the stored compounds (Table S5), if assume the pool size of an average seedling. Therefore, and because no seedlings died during the same period, it is unlikely that resin ducts have been significantly damaged and were the origin of the MT burst. However, decreased membrane integrity of more sensitive individuals may have facilitated the release of nonspecific MT. Furthermore, MT precursors can be formed in the plastidic methylerythritol phosphate pathway (MEP) (Zeidler and Lichtenthaler 2001). As the MEP pathway is promoted under heat and light stress (Harley et al. 1998), and is well coupled to the abscisic acid sensing network (Asad et al. 2019), increased synthesis of MT by dying seedlings could be explained by a higher stress sensitivity. In summary, we found that the onset of lethal stress induces a distinct BVOC emission composition, which was already detectable about 14 days before mortality actually occurred. This indication of mortality started considerably earlier than any clear trend in gas exchange rates.

Concluding, we found VOC emissions from Aleppo pine seedlings to respond specifically to stress-type and stressfrequency. The reduced temperature sensitivity of monoterpene emissions during a second heatwave was not related to storage depletion in shoot tissues, but likely caused by stress-induced impairment of de novo synthesis and intratissue localization. Moreover, we found a distinct response in MT, acetaldehyde emissions to precede seedling mortality with methanol as an indicator for lethality under heat and combined heat-drought stress. We did, however, not investigate different ontogenetic stages, which means that a species might acclimate to heatwaves and drought conditions and that emission responses of adult individuals might differ from those of seedlings. In fact, eddy-covariance measurements in different Aleppo pine stands indicate that emissions at the Yatir forest are smaller than at stands with less extreme conditions (Seco et al. 2017), which could be interpreted as a long-term acclimation. Understanding these signals, might help optimizing management for stress mitigation in precision farming or tree planting (Kravitz et al. 2016; Lüttge and Buckeridge 2020), and pave the way to new conceptual modelling frameworks towards characterizing stress severity related to tree mortality.

Supplementary Information The online version contains supplementary material available at https://doi.org/10.1007/s00442-021-04905-y.

Acknowledgements We would like to thank Marielle Gattmann and Lena Müller for support during the experiment and Baris Weber and Ina Zimmer for technical help during GC-Ms analysis. This study was funded by the German Research Foundation through its German-Israeli project cooperation program (SCHM 2736/2-1 and YA 274/1-1) and by the German Federal Ministry of Education and Research (BMBF), through the Helmholtz Association and its research program ATMO. BB and NKR acknowledge support from the German Research Foundation through its Emmy Noether Program (RU 1657/2-1). We are thankful to all reviewers, who helped to improve this manuscript. This manuscript is to be published as part of a Special Issue honoring Russ Monson. The authors appreciate Russ' contribution to highlighting the $\mathrm{CO}_{2}$ effects on isoprene emissions, and lively discussions about BVOC emissions modelling.

Author contribution statement $\mathrm{BB}$ wrote the manuscript with input from all co-authors. BB, IB, NKR, RG and AA designed the experiment, IB, BB and NKR conducted the experiment and IB, BB and EGC analyzed the BVOC and gas exchange data. DNS performed statistical analyses and AG performed the endogenous terpenoid analyses.

Funding Open Access funding enabled and organized by Projekt DEAL. This study was funded by the German Research Foundation through its German-Israeli project cooperation program (SCHM 2736/2-1 and YA 274/1-1) and by the German Federal Ministry of Education and Research (BMBF), through the Helmholtz Association and its research program ATMO. BB and NKR acknowledge support 
from the German Research Foundation through its Emmy Noether Program (RU 1657/2-1).

Availability of data and material The dataset generated during and/or analysed during this study is made available in the Repository PANGAEA, https://doi.pangaea.de/10.1594/PANGAEA.923768.

\section{Declarations}

Conflict of interest The authors declare that they have no conflict of interest.

Open Access This article is licensed under a Creative Commons Attribution 4.0 International License, which permits use, sharing, adaptation, distribution and reproduction in any medium or format, as long as you give appropriate credit to the original author(s) and the source, provide a link to the Creative Commons licence, and indicate if changes were made. The images or other third party material in this article are included in the article's Creative Commons licence, unless indicated otherwise in a credit line to the material. If material is not included in the article's Creative Commons licence and your intended use is not permitted by statutory regulation or exceeds the permitted use, you will need to obtain permission directly from the copyright holder. To view a copy of this licence, visit http://creativecommons.org/licenses/by/4.0/.

\section{References}

Anderegg WRL, Anderegg LDL, Kerr KL, Trugman AT (2019) Widespread drought-induced tree mortality at dry range edges indicates that climate stress exceeds species' compensating mechanisms. Glob Chang Biol 25:3793-3802. https://doi.org/10.1111/ gcb. 14771

Asad MAU, Zakari SA, Zhao Q, Zhou L, Ye Y, Cheng F (2019) Abiotic stresses intervene with $\mathrm{ABA}$ signaling to induce destructive metabolic pathways leading to death: premature leaf senescence in Plants. Int J Mol Sci. https://doi.org/10.3390/ijms20020256

Atzmon N, Moshe Y, Schiller G (2004) Ecophysiological response to severe drought in Pinus halepensis Mill. trees of two provenances. Plant Ecol 171:15-22. https://doi.org/10.1023/B:VEGE. 0000029371.44518 .38

Baldwin JW, Dessy JB, Vecchi GA, Oppenheimer M (2019) Temporally compound heat wave events and global warming: an emerging hazard. Earth's Future 7:411-427. https://doi.org/10.1029/ 2018EF000989

Bamberger I, Ruehr NK, Schmitt M, Gast A, Wohlfahrt G, Arneth A (2017) Isoprene emission and photosynthesis during heatwaves and drought in black locust. Biogeosciences 14:3649-3667. https://doi.org/10.5194/bg-14-3649-2017

Behnke K, Ghirardo A, Janz D, Kanawati B, Esperschütz J, Zimmer I, Schmitt-Kopplin P, Niinemets Ü, Polle A, Schnitzler JP, Rosenkranz M (2013) Isoprene function in two contrasting poplars under salt and sunflecks. Tree Physiol 33:562-578. https://doi.org/10. 1093/treephys/tpt018

Birami B, Gattmann M, Heyer AG, Grote R, Arneth A, Ruehr NK (2018) Heat waves alter carbon allocation and increase mortality of Aleppo pine under dry conditions. Front For Glob Change 1:1285. https://doi.org/10.3389/ffgc.2018.00008

Blanch J-S, Peñuelas J, Llusià J (2007) Sensitivity of terpene emissions to drought and fertilization in terpene-storing Pinus halepensis and non-storing Quercus ilex. Physiol Plant 131:211-225. https:// doi.org/10.1111/j.1399-3054.2007.00944.x
Box GEP, Jenkins GM, Reinsel GC, Ljung GM (2016) Time series analysis: forecasting and control, 5th edn. Wiley Series in Probability and Statistics. John Wiley \& Sons Inc, Hoboken

Bracho-Nunez A, Knothe NM, Costa WR, Maria Astrid LR, Kleiss B, Rottenberger S, Piedade MTF, Kesselmeier J (2012) Root anoxia effects on physiology and emissions of volatile organic compounds (VOC) under short- and long-term inundation of trees from Amazonian floodplains. Springerplus 1:9. https://doi.org/ 10.1186/2193-1801-1-9

Brodribb TJ, Powers J, Cochard H, Choat B (2020) Hanging by a thread? Forests and drought. Science 368:261-266. https://doi. org/10.1126/science.aat7631

Brunner I, Herzog C, Dawes MA, Arend M, Sperisen C (2015) How tree roots respond to drought. Front Plant Sci 6:547. https://doi. org/10.3389/fpls.2015.00547

Burnham KP, Anderson DR (2004) Model selection and multimodel inference. Springer, New York

Cappellin L, Karl T, Probst M, Ismailova O, Winkler PM, Soukoulis C, Aprea E, Märk TD, Gasperi F, Biasioli F (2012) On quantitative determination of volatile organic compound concentrations using proton transfer reaction time-of-flight mass spectrometry. Environ Sci Technol 46:2283-2290. https://doi.org/10.1021/ es203985t

Celedon JM, Bohlmann J (2019) Oleoresin defenses in conifers: chemical diversity, terpene synthases and limitations of oleoresin defense under climate change. New Phytol 224:1444-1463. https://doi.org/10.1111/nph.15984

Choat B, Brodribb TJ, Brodersen CR, Duursma RA, López R, Medlyn BE (2018) Triggers of tree mortality under drought. Nature 558:531-539. https://doi.org/10.1038/s41586-018-0240-x

Clarke SM, Mur LAJ, Wood JE, Scott IM (2004) Salicylic acid dependent signaling promotes basal thermotolerance but is not essential for acquired thermotolerance in Arabidopsis thaliana. Plant $\mathbf{J}$ 38:432-447. https://doi.org/10.1111/j.1365-313X.2004.02054.x

Colombo SJ, Timmer VR (1992) Limits of tolerance to high temperatures causing direct and indirect damage to black spruce. Tree Physiol 11:95-104. https://doi.org/10.1093/treephys/11.1.95

Dani KGS, Jamie IM, Prentice IC, Atwell BJ (2015) Species-specific photorespiratory rate, drought tolerance and isoprene emission rate in plants. Plant Signal Behav 10:e990830. https://doi.org/10. 4161/15592324.2014.990830

Daniell JW, Chappell WE, Couch HB (1969) Effect of sublethal and lethal temperature on plant cells. Plant Physiol 44:1684-1689. https://doi.org/10.1104/pp.44.12.1684

de Gouw JA, Howard CJ, Custer TG, Fall R (1999) Emissions of volatile organic compounds from cut grass and clover are enhanced during the drying process. Geophys Res Lett 26:811-814. https:// doi.org/10.1029/1999GL900076

Dorokhov YL, Sheshukova EV, Komarova TV (2018) Methanol in plant life. Front Plant Sci 9:1623. https://doi.org/10.3389/fpls. 2018.01623

Duarte AG, Katata G, Hoshika Y, Hossain M, Kreuzwieser J, Arneth A, Ruehr NK (2016) Immediate and potential long-term effects of consecutive heat waves on the photosynthetic performance and water balance in Douglas-fir. J Plant Physiol 205:57-66. https:// doi.org/10.1016/j.jplph.2016.08.012

Eller ASD, Young LL, Trowbridge AM, Monson RK (2016) Differential controls by climate and physiology over the emission rates of biogenic volatile organic compounds from mature trees in a semi-arid pine forest. Oecologia 180:345-358. https://doi.org/ 10.1007/s00442-015-3474-4

Escandón M, Cañal MJ, Pascual J, Pinto G, Correia B, Amaral J, Meijón $M$ (2016) Integrated physiological and hormonal profile of heat-induced thermotolerance in Pinus radiata. Tree Physiol 36:63-77. https://doi.org/10.1093/treephys/tpv127 
Fall R (2003) Abundant oxygenates in the atmosphere: a biochemical perspective. Chem Rev 103:4941-4952. https://doi.org/10.1021/ cr0206521

Fall R, Karl T, Hansel A, Jordan A, Lindinger W (1999) Volatile organic compounds emitted after leaf wounding: On-line analysis by proton-transfer-reaction mass spectrometry. J Geophys Res 104:15963-15974. https://doi.org/10.1029/1999JD900144

Filella I, Peñuelas J, Llusià J (2006) Dynamics of the enhanced emissions of monoterpenes and methyl salicylate, and decreased uptake of formaldehyde, by Quercus ilex leaves after application of jasmonic acid. New Phytol 169:135-144. https://doi.org/ 10.1111/j.1469-8137.2005.01570.x

Filella I, Peñuelas J, Seco R (2009) Short-chained oxygenated VOC emissions in Pinus halepensis in response to changes in water availability. Acta Physiol Plant 31:311-318. https://doi.org/10. 1007/s11738-008-0235-6

Fuentes J, Hayden B, Garstang M, Lerdau M, Fitzjarrald D, Baldocchi D, Monson R, Lamb B, Geron C (2001) New directions: VOCs and biosphere-atmosphere feedbacks. Atmos Environ 35:189191. https://doi.org/10.1016/S1352-2310(00)00365-4

Ghirardo A, Koch K, Taipale R, Zimmer I, Schnitzler J-P, Rinne J (2010) Determination of de novo and pool emissions of terpenes from four common boreal/alpine trees by $13 \mathrm{CO} 2$ labelling and PTR-MS analysis. Plant Cell Environ 33:781-792. https://doi. org/10.1111/j.1365-3040.2009.02104.X

Ghirardo A, Heller W, Fladung M, Schnitzler J-P, Schroeder H (2012) Function of defensive volatiles in pedunculate oak (Quercus robur) is tricked by the moth Tortrix viridana. Plant Cell Environ 35:2192-2207. https://doi.org/10.1111/j.1365-3040.2012. 02545.x

Ghirardo A, Wright LP, Bi Z, Rosenkranz M, Pulido P, Rodríguez-Concepción M, Niinemets Ü, Brüggemann N, Gershenzon J, Schnitzler J-P (2014) Metabolic flux analysis of plastidic isoprenoid biosynthesis in poplar leaves emitting and nonemitting isoprene. Plant Physiol 165:37-51. https://doi.org/10.1104/pp.114.236018

Ghirardo A, Lindstein F, Koch K, Buegger F, Schloter M, Albert A, Michelsen A, Winkler JB, Schnitzler J-P, Rinnan R (2020) Origin of volatile organic compound emissions from subarctic tundra under global warming. Glob Chang Biol 26:1908-1925. https:// doi.org/10.1111/gcb.14935

Grote R, Morfopoulos C, Niinemets Ü, Sun Z, Keenan TF, Pacifico F, Butler T (2014) A fully integrated isoprenoid emissions model coupling emissions to photosynthetic characteristics. Plant Cell Environ 37:1965-1980. https://doi.org/10.1111/pce.12326

Grote R, Sharma M, Ghirardo A, Schnitzler J-P (2019) A New modeling approach for estimating abiotic and biotic stress-induced de novo emissions of biogenic volatile organic compounds from plants. Front For Glob Change 2:224. https://doi.org/10.3389/ ffgc. 2019.00026

Guenther AB, Zimmerman PR, Harley PC, Monson RK, Fall R (1993) Isoprene and monoterpene emission rate variability: Model evaluations and sensitivity analyses. J Geophys Res 98:12609. https:// doi.org/10.1029/93JD00527

Guidolotti G, Pallozzi E, Gavrichkova O, Scartazza A, Mattioni M, Loreto F, Calfapietra C (2019) Emission of constitutive isoprene, induced monoterpenes, and other volatiles under high temperatures in Eucalyptus camaldulensis: A $13 \mathrm{C}$ labelling study. Plant Cell Environ 42:1929-1938. https://doi.org/10.1111/pce.13521

Gupta A, Rico-Medina A, Caño-Delgado AI (2020) The physiology of plant responses to drought. Science 368:266-269. https://doi. org/10.1126/science.aaz7614

Hammond WM, Yu K, Wilson LA, Will RE, Anderegg WRL, Adams HD (2019) Dead or dying? Quantifying the point of no return from hydraulic failure in drought-induced tree mortality. New Phytol 223:1834-1843. https://doi.org/10.1111/nph.15922
Harley P, Fridd-Stroud V, Greenberg J, Guenther A, Vasconcellos P (1998) Emission of 2-methyl-3-buten-2-ol by pines: A potentially large natural source of reactive carbon to the atmosphere. J Geophys Res 103:25479-25486. https://doi.org/10.1029/98JD00820

Harper KL, Unger N (2018) Global climate forcing driven by altered BVOC fluxes from 1990 to 2010 land cover change in maritime Southeast Asia. Atmos Chem Phys 18:16931-16952. https://doi. org/10.5194/acp-18-16931-2018

Hartmann H, Schuldt B, Sanders TGM, Macinnis-Ng C, Boehmer HJ, Allen CD, Bolte A, Crowther TW, Hansen MC, Medlyn BE, Ruehr NK, Anderegg WRL (2018a) Monitoring global tree mortality patterns and trends. Report from the VW symposium "Crossing scales and disciplines to identify global trends of tree mortality as indicators of forest health." New Phytol 217:984987. https://doi.org/10.1111/nph.14988

Hartmann H, Moura CF, Anderegg WRL, Ruehr NK, Salmon Y, Allen CD, Arndt SK, Breshears DD, Davi H, Galbraith D, Ruthrof KX, Wunder J, Adams HD, Bloemen J, Cailleret M, Cobb R, Gessler A, Grams TEE, Jansen S, Kautz M, Lloret F, O'Brien M (2018b) Research frontiers for improving our understanding of drought-induced tree and forest mortality. New Phytol 218:15-28. https://doi.org/10.1111/nph.15048

Harvey CM, Sharkey TD (2016) Exogenous isoprene modulates gene expression in unstressed Arabidopsis thaliana plants. Plant Cell Environ 39:1251-1263. https://doi.org/10.1111/pce.12660

Heil M, Ton J (2008) Long-distance signalling in plant defence. Trends Plant Sci 13:264-272. https://doi.org/10.1016/j.tplan ts.2008.03.005

Hüve K, Bichele I, Rasulov B, Niinemets U (2011) When it is too hot for photosynthesis: heat-induced instability of photosynthesis in relation to respiratory burst, cell permeability changes and $\mathrm{H}_{2} \mathrm{O}_{2}$ formation. Plant Cell Environ 34:113-126. https://doi. org/10.1111/j.1365-3040.2010.02229.x

Jacob DJ (2005) Global budget of methanol: Constraints from atmospheric observations. J Geophys Res 110:955. https://doi.org/ 10.1029/2004JD005172

Janson R, de Serves C (2001) Acetone and monoterpene emissions from the boreal forest in northern Europe. Atmos Environ 35:4629-4637. https://doi.org/10.1016/S1352-2310(01) 00160-1

Jardine KJ, Chambers JQ, Holm J, Jardine AB, Fontes CG, Zorzanelli RF, Meyers KT, de Souza VF, Garcia S, Gimenez BO, Piva LR, de O, Higuchi N, Artaxo P, Martin S, Manzi AO, (2015) Green leaf volatile emissions during high temperature and drought stress in a central Amazon rainforest. Plants (Basel) 4:678-690. https://doi.org/10.3390/plants4030678

Joensuu J, Altimir N, Hakola H, Rostás M, Raivonen M, Vestenius M, Aaltonen H, Riederer M, Bäck J (2016) Role of needle surface waxes in dynamic exchange of mono- and sesquiterpenes. Atmos Chem Phys 16:7813-7823. https://doi.org/10.5194/ acp-16-7813-2016

Joó É, Dewulf J, Amelynck C, Schoon N, Pokorska O, Šimpraga M, Steppe K, Aubinet M, van Langenhove H (2011) Constitutive versus heat and biotic stress induced BVOC emissions in Pseudotsuga menziesii. Atmos Environ 45:3655-3662. https://doi.org/ 10.1016/j.atmosenv.2011.04.048

Jud W, Vanzo E, Li Z, Ghirardo A, Zimmer I, Sharkey TD, Hansel A, Schnitzler J-P (2016) Effects of heat and drought stress on postillumination bursts of volatile organic compounds in isopreneemitting and non-emitting poplar. Plant Cell Environ 39:12041215. https://doi.org/10.1111/pce.12643

Karl T, Curtis AJ, Rosenstiel TN, Monson RK, Fall R (2002) Transient releases of acetaldehyde from tree leaves - products of a pyruvate overflow mechanism? Plant Cell Environ 25:1121-1131. https:// doi.org/10.1046/j.1365-3040.2002.00889.x 
Karl T, Guenther A, Turnipseed A, Patton EG, Jardine K (2008) Chemical sensing of plant stress at the ecosystem scale. Biogeosciences 5:1287-1294. https://doi.org/10.5194/bg-5-1287-2008

Kelsey RG, Joseph G, McWilliams MG (2011) Ethanol synthesis by anoxic root segments from five cedar species relates to their habitat attributes but not their known differences in vulnerability to Phytophthora lateralis root disease. Can J For Res 41:1202-1211. https://doi.org/10.1139/X11-043

Kim J-M, Sasaki T, Ueda M, Sako K, Seki M (2015) Chromatin changes in response to drought, salinity, heat, and cold stresses in plants. Front Plant Sci 6:114. https://doi.org/10.3389/fpls. 2015.00114

Kimmerer TW, Stringer MA (1988) Alcohol dehydrogenase and ethanol in the stems of trees: Evidence for anaerobic metabolism in the vascular cambium. Plant Physiol 87:693-697. https://doi.org/ 10.1104/pp.87.3.693

Kleist E, Mentel TF, Andres S, Bohne A, Folkers A, Kiendler-Scharr A, Rudich Y, Springer M, Tillmann R, Wildt J (2012) Irreversible impacts of heat on the emissions of monoterpenes, sesquiterpenes, phenolic BVOC and green leaf volatiles from several tree species. Biogeosciences 9:5111-5123. https://doi.org/10.5194/ bg-9-5111-2012

Körner C (2019) No need for pipes when the well is dry-a comment on hydraulic failure in trees. Tree Physiol 39:695-700. https://doi. org/10.1093/treephys/tpz030

Kornhuber K, Osprey S, Coumou D, Petri S, Petoukhov V, Rahmstorf S, Gray L (2019) Extreme weather events in early summer 2018 connected by a recurrent hemispheric wave-7 pattern. Environ Res Lett 14:54002. https://doi.org/10.1088/1748-9326/ab13bf

Korol L, Schiller G (1996) Relations between native Israeli and Jordanian Aleppo pine (Pinus halepensis Mill.) based on Allozyme analysis: A Note. For Genet 3:197-202

Kravitz B, Guenther AB, Gu L, Karl T, Kaser L, Pallardy SG, Peñuelas J, Potosnak MJ, Seco R (2016) A new paradigm of quantifying ecosystem stress through chemical signatures. Ecosphere 7:23. https://doi.org/10.1002/ecs2.1559

Kreuzwieser J, Scheerer U, Rennenberg H (1999) Metabolic origin of acetaldehyde emitted by poplar (Populus tremula x P. alba) trees. J Exp Bot 50:757-765. https://doi.org/10.1093/jxb/50.335.757

Llusià J, Peñuelas J, Alessio GA, Estiarte M (2008) Contrasting species-specific, compound-specific, seasonal, and interannual responses of foliar isoprenoid emissions to experimental drought in a Mediterranean Shrubland. Int J Plant Sci 169:637-645. https://doi.org/10.1086/533603

Llusia J, Roahtyn S, Yakir D, Rotenberg E, Seco R, Guenther A, Peñuelas J (2016) Photosynthesis, stomatal conductance and terpene emission response to water availability in dry and mesic Mediterranean forests. Trees 30:749-759. https://doi.org/10.1007/ s00468-015-1317-x

Loreto F, Forster A, Durr M, Csiky O, Seufert G (1998) On the monoterpene emission under heat stress and on the increased thermotolerance of leaves of Quercus ilex L. fumigated with selected monoterpenes. Plant Cell Environ 21:101-107. https:// doi.org/10.1046/j.1365-3040.1998.00268.x

Loreto F, Barta C, Brilli F, Nogues I (2006) On the induction of volatile organic compound emissions by plants as consequence of wounding or fluctuations of light and temperature. Plant Cell Environ 29:1820-1828. https://doi.org/10.1111/j.1365-3040. 2006.01561.x

Lüpke M, Leuchner M, Steinbrecher R, Menzel A (2017) Quantification of monoterpene emission sources of a conifer species in response to experimental drought. AoB Plants. https://doi.org/ 10.1093/aobpla/plx045

Lüttge U, Buckeridge M (2020) Trees: Structure and function and the challenges of urbanization. Trees 26:751. https://doi.org/10.1007/ s00468-020-01964-1
Mahajan P, Singh HP, Kaur S, Batish DR, Kohli RK (2019) $\beta$-Pinene moderates $\mathrm{Cr}(\mathrm{VI})$ phytotoxicity by quenching reactive oxygen species and altering antioxidant machinery in maize. Environ Sci Pollut Res Int 26:456-463. https://doi.org/10.1007/ s11356-018-3562-1

Mauri A, Di Leo M, Rigo D de, Caudullo G (2016) Pinus halepensis and Pinus brutia in Europe: distribution, habitat, usage and threats. In: San-Miguel-Ayanz J, de Rigo D, Caudullo G, Houston Durrant T, Mauri A (Eds.) European Atlas of Forest Tree Species. Publ. Off. EU, Luxembourg, pp. e0166b8+

McDonald AG, Dare PH, Gifford JS, Steward D, Riley S (2002) Assessment of air emissions from industrial kiln drying of Pinus radiata wood. Holz als Roh- und Werkstoff 60:181-190. https:// doi.org/10.1007/s00107-002-0293-1

Monson RK, Holland EA (2001) Biospheric trace gas fluxes and their control over tropospheric chemistry. Annu Rev Ecol Syst 32:547-576. https://doi.org/10.1146/annurev.ecolsys.32.081501. 114136

Nagegowda DA (2010) Plant volatile terpenoid metabolism: biosynthetic genes, transcriptional regulation and subcellular compartmentation. FEBS Lett 584:2965-2973. https://doi.org/10. 1016/j.febslet.2010.05.045

Nakagawa S, Schielzeth H, O'Hara RB (2013) A general and simple method for obtaining R2 from generalized linear mixedeffects models. Methods Ecol Evol 4:133-142. https://doi.org/ 10.1111/j.2041-210x.2012.00261.x

Niinemets Ü (2018) When leaves go over the thermal edge. Plant Cell Environ 41:1247-1250. https://doi.org/10.1111/pce.13184

Niinemets U, Seufert G, Steinbrecher R, Tenhunen JD (2002) A model coupling foliar monoterpene emissions to leaf photosynthetic characteristics in Mediterranean evergreen Quercus species. New Phytol 153:257-275. https://doi.org/10.1046/j. 0028-646X.2001.00324.x

Niinemets Ü, Monson RK, Arneth A, Ciccioli P, Kesselmeier J, Kuhn U, Noe SM, Peñuelas J, Staudt M (2010) The leaf-level emission factor of volatile isoprenoids: Caveats, model algorithms, response shapes and scaling. Biogeosciences 7:1809-1832. https://doi.org/10.5194/bg-7-1809-2010

Niinemets Ü, Kuhn U, Harley PC, Staudt M, Arneth A, Cescatti A, Ciccioli P, Copolovici L, Geron C, Guenther A, Kesselmeier J, Lerdau MT, Monson RK, Peñuelas J (2011) Estimations of isoprenoid emission capacity from enclosure studies: Measurements, data processing, quality and standardized measurement protocols. Biogeosciences 8:2209-2246. https://doi.org/ 10.5194/bg-8-2209-2011

Nogués I, Medori M, Calfapietra C (2015) Limitations of monoterpene emissions and their antioxidant role in Cistus sp. under mild and severe treatments of drought and warming. Environ Exp Bot 119:76-86. https://doi.org/10.1016/j.envexpbot.2015. 06.001

Oksanen J (2011) Multivariate analysis of ecological communities in $\mathrm{R}$ : vegan tutorial. R package version $1(7): 1-43$

Oksanen J, Blanchet FG, Friendly M, Kindt R, Legendre P, McGlinn D, Minchin PR, O'Hara RB, Simpson GL, Solymos P, tevens MHH, Szoecs E, Wagner Helene (2013) Package 'vegan': Community ecology package. version, 2(5-6):1-295

Ormeño E, Mévy JP, Vila B, Bousquet-Mélou A, Greff S, Bonin G, Fernandez C (2007) Water deficit stress induces different monoterpene and sesquiterpene emission changes in Mediterranean species. Relationship between terpene emissions and plant water potential. Chemosphere 67:276-284. https://doi.org/10. 1016/j.chemosphere.2006.10.029

Ormeño E, Goldstein A, Niinemets Ü (2011) Extracting and trapping biogenic volatile organic compounds stored in plant species. TrAC, Trends Anal Chem 30:978-989. https://doi.org/10.1016/j. trac.2011.04.006 
Panek JA, Goldstein AH (2001) Response of stomatal conductance to drought in ponderosa pine: implications for carbon and ozone uptake. Tree Physiol 21:337-344. https://doi.org/10.1093/treep hys/21.5.337

Peñuelas J, Llusià J (1999) Short-term responses of terpene emission rates to experimental changes of PFD in Pinus halepensis and Quercus ilex in summer field conditions. Environ Exp Bot 42:6168. https://doi.org/10.1016/S0098-8472(99)00018-0

Porter WC, Heald CL (2019) The mechanisms and meteorological drivers of the summertime ozone-temperature relationship. Atmos Chem Phys 19:13367-13381. https://doi.org/10.5194/ acp-19-13367-2019

Portillo-Estrada M, Kazantsev T, Talts E, Tosens T, Niinemets Ü (2015) Emission timetable and quantitative patterns of woundinduced volatiles across different leaf damage treatments in Aspen (Populus Tremula). J Chem Ecol 41:1105-1117. https:// doi.org/10.1007/s10886-015-0646-y

Pucciariello C, Banti V, Perata P (2012) ROS signaling as common element in low oxygen and heat stresses. Plant Physiol Biochem 59:3-10. https://doi.org/10.1016/j.plaphy.2012.02.016

Rissanen K, Hölttä T, Bäck J (2018) Transpiration directly regulates the emissions of water-soluble short-chained OVOCs. Plant Cell Environ 41:2288-2298. https://doi.org/10.1111/pce.13318

Rissanen K, Vanhatalo A, Salmon Y, Bäck J, Hölttä T (2020) Stem emissions of monoterpenes, acetaldehyde and methanol from Scots pine (Pinus sylvestris L.) affected by tree-water relations and cambial growth. Plant Cell Environ. https://doi.org/ $10.1111 /$ pce. 13778

Ruehr NK, Gast A, Weber C, Daub B, Arneth A (2016) Water availability as dominant control of heat stress responses in two contrasting tree species. Tree Physiol 36:164-178. https://doi.org/ 10.1093/treephys/tpv102

Ruehr NK, Grote R, Mayr S, Arneth A (2019) Beyond the extreme: recovery of carbon and water relations in woody plants following heat and drought stress. Tree Physiol 39:1285-1299. https://doi.org/10.1093/treephys/tpz032

Schiller G, Atzmon N (2009) Performance of Aleppo pine (Pinus halepensis) provenances grown at the edge of the Negev desert: A review. J Arid Environ 73:1051-1057. https://doi.org/10. 1016/j.jaridenv.2009.06.003

Schurgers G, Arneth A, Holzinger R, Goldstein AH (2009) Processbased modelling of biogenic monoterpene emissions combining production and release from storage. Atmos Chem Phys 9:3409-3423. https://doi.org/10.5194/acp-9-3409-2009

Scott ER, Li X, Kfoury N, Morimoto J, Han W-Y, Ahmed S, Cash SB, Griffin TS, Stepp JR, Robbat A, Orians CM (2019) Interactive effects of drought severity and simulated herbivory on tea (Camellia sinensis) volatile and non-volatile metabolites. Environ Exp Bot 157:283-292. https://doi.org/10.1016/j.envex pbot.2018.10.025

Seco R, Peñuelas J, Filella I (2008) Formaldehyde emission and uptake by Mediterranean trees Quercus ilex and Pinus halepensis. Atmos Environ 42:7907-7914. https://doi.org/10.1016/j. atmosenv.2008.07.006

Seco R, Karl T, Guenther A, Hosman KP, Pallardy SG, Gu L, Geron C, Harley P, Kim S (2015) Ecosystem-scale volatile organic compound fluxes during an extreme drought in a broadleaf temperate forest of the Missouri Ozarks (central USA). Glob Chang Biol 21:3657-3674. https://doi.org/10.1111/gcb.12980

Seco R, Karl T, Turnipseed A, Greenberg J, Guenther A, Llusia J, Peñuelas J, Dicken U, Rotenberg E, Kim S, Yakir D (2017) Springtime ecosystem-scale monoterpene fluxes from Mediterranean pine forests across a precipitation gradient. Agric For Meteorol 237-238:150-159. https://doi.org/10.1016/j.agrfo rmet.2017.02.007
Shao M, Wildt J (2002) Quantification of acetone emission from pine plants. Sci China Ser B 45:532. https://doi.org/10.1360/ 02 yb9070

Shulaev V, Silverman P, Raskin I (1997) Airborne signalling by methyl salicylate in plant pathogen resistance. Nature 385:718721. https://doi.org/10.1038/385718a0

Snow MD, Bard RR, Olszyk DM, Minster LM, Hager AN, Tingey DT (2003) Monoterpene levels in needles of Douglas fir exposed to elevated $\mathrm{CO} 2$ and temperature. Physiol Plant 117:352-358. https://doi.org/10.1034/j.1399-3054.2003. 00035.X

Song Y, Chen Q, Ci D, Shao X, Zhang D (2014) Effects of high temperature on photosynthesis and related gene expression in poplar. BMC Plant Biol 14:111. https://doi.org/10.1186/ 1471-2229-14-111

Spinelli F, Cellini A, Marchetti L, Mudigere K, Piovene C (2011) Emission and Function of Volatile Organic Compounds in Response to Abiotic Stress. In: Shanker A (ed) Abiotic Stress in Plants Mechanisms and Adaptations. InTech, pp 1-29

Sporre MK, Blichner SM, Karset IHH, Makkonen R, Berntsen TK (2019) BVOC-aerosol-climate feedbacks investigated using NorESM. Atmos Chem Phys 19:4763-4782. https://doi.org/10. 5194/acp-19-4763-2019

Staudt M, Bourgeois I, Al Halabi R, Song W, Williams J (2017) New insights into the parametrization of temperature and light responses of mono - and sesquiterpene emissions from Aleppo pine and rosemary. Atmos Environ 152:212-221. https://doi.org/ 10.1016/j.atmosenv.2016.12.033

Taipale R, Kajos MK, Patokoski J, Rantala P, Ruuskanen TM, Rinne J (2011) Role of de novo biosynthesis in ecosystem scale monoterpene emissions from a boreal Scots pine forest. Biogeosciences 8:2247-2255. https://doi.org/10.5194/bg-8-2247-2011

Tatarinov F, Rotenberg E, Maseyk K, Ogée J, Klein T, Yakir D (2016) Resilience to seasonal heat wave episodes in a Mediterranean pine forest. New Phytol 210:485-496. https://doi.org/10.1111/ nph.13791

Tawfik MM, Yamato KT, Kohchi T, Koeduka T, Matsui K (2017) $\mathrm{n}$-Hexanal and (Z)-3-hexenal are generated from arachidonic acid and linolenic acid by a lipoxygenase in Marchantia polymorpha L. Biosci Biotechnol Biochem 81:1148-1155. https://doi.org/10. 1080/09168451.2017.1285688

TerBraak CJF (1986) Canonical Correspondence Analysis: A New Eigenvector Technique for Multivariate Direct Gradient Analysis. Ecology 67:1167-1179. https://doi.org/10.2307/1938672

Tohmura S-i, Ishikawa A, Miyamoto K, Inoue A (2012) Acetaldehyde emission from wood induced by the addition of ethanol. J Wood Sci 58:57-63. https://doi.org/10.1007/s10086-011-1215-9

Turan S, Kask K, Kanagendran A, Li S, Anni R, Talts E, Rasulov B, Kännaste A, Niinemets Ü (2019) Lethal heat stress-dependent volatile emissions from tobacco leaves: what happens beyond the thermal edge? J Exp Bot 70:5017-5030. https://doi.org/10. 1093/jxb/erz255

Turner GW, Parrish AN, Zager JJ, Fischedick JT, Lange BM (2019) Assessment of flux through oleoresin biosynthesis in epithelial cells of loblolly pine resin ducts. J Exp Bot 70:217-230. https:// doi.org/10.1093/jxb/ery338

Vanhatalo A, Ghirardo A, Juurola E, Schnitzler J-P, Zimmer I, Hellén H, Hakola H, Bäck J (2018) Long-term dynamics of monoterpene synthase activities, monoterpene storage pools and emissions in boreal Scots pine. Biogeosciences 15:5047-5060. https:// doi.org/10.5194/bg-15-5047-2018

Vanhatalo A, Aalto J, Chan T, Hölttä T, Kolari P, Rissanen K, Kabiri K, Hellén H, Bäck J (2020) Scots Pine Stems as Dynamic Sources of Monoterpene and Methanol Emissions. Front For Glob Change 2:1331. https://doi.org/10.3389/ffgc.2019.00095 
Vanzo E, Jud W, Li Z, Albert A, Domagalska MA, Ghirardo A, Niederbacher B, Frenzel J, Beemster GTS, Asard H, Rennenberg H, Sharkey TD, Hansel A, Schnitzler J-P (2015) Facing the future: effects of short-term climate extremes on isoprene-emitting and nonemitting poplar. Plant Physiol 169:560-575. https://doi.org/ 10.1104/pp.15.00871

Vickers CE, Gershenzon J, Lerdau MT, Loreto F (2009) A unified mechanism of action for volatile isoprenoids in plant abiotic stress. Nat Chem Biol 5:283-291. https://doi.org/10.1038/nchem bio. 158

Williams AP, Allen CD, Macalady AK, Griffin D, Woodhouse CA, Meko DM, Swetnam TW, Rauscher SA, Seager R, GrissinoMayer HD, Dean JS, Cook ER, Gangodagamage C, Cai M, McDowell NG (2013) Temperature as a potent driver of regional forest drought stress and tree mortality. Nature Clim Change 3:292-297. https://doi.org/10.1038/nclimate1693

Wu H-C, Bulgakov VP, Jinn T-L (2018) Pectin methylesterases: cell wall remodeling proteins are required for plant response to heat stress. Front Plant Sci 9:1612. https://doi.org/10.3389/fpls.2018. 01612

Yáñez-Serrano AM, Mahlau L, Fasbender L, Byron J, Williams J, Kreuzwieser J, Werner C (2019) Heat stress increases the use of cytosolic pyruvate for isoprene biosynthesis. J Exp Bot 70:58275838. https://doi.org/10.1093/jxb/erz353

Yazaki K, Arimura G-I, Ohnishi T (2017) "Hidden" Terpenoids in Plants: Their Biosynthesis, Localization and Ecological Roles. Plant Cell Physiol 58:1615-1621. https://doi.org/10.1093/pcp/ pcx 123

Zeidler J, Lichtenthaler HK (2001) Biosynthesis of 2-methyl-3-buten2-ol emitted from needles of Pinus ponderosa via the non-mevalonate DOXP/MEP pathway of isoprenoid formation. Planta 213:323-326. https://doi.org/10.1007/s004250100562

Zhao DF, Buchholz A, Tillmann R, Kleist E, Wu C, Rubach F, Kiendler-Scharr A, Rudich Y, Wildt J, Mentel TF (2017) Environmental conditions regulate the impact of plants on cloud formation. Nat Commun 8:14067. https://doi.org/10.1038/ncomms 14067 